\title{
2-Cl-IB-MECA regulates the proliferative and drug resistance pathways, and facilitates chemosensitivity in pancreatic and liver cancer cell lines
}

\author{
JANA KOTULOVA, KATERINA LONOVA, AGATA KUBICKOVA, JANA VRBKOVA, \\ PAVLA KOURILOVA, MARIAN HAJDUCH and PETR DZUBAK \\ Institute of Molecular and Translational Medicine, Faculty of Medicine and Dentistry, \\ Palacky University Olomouc, 77900 Olomouc, Czech Republic
}

Received October 11, 2021; Accepted December 14, 2021

DOI: $10.3892 /$ ijmm.2022.5086

\begin{abstract}
Specific $A_{3}$ adenosine receptor $\left(A_{3} A R\right)$ agonist, 2-chloro-N6-(3-iodobenzyl)-5'-N-methylcarboxamidoadenosine (2-Cl-IB-MECA), demonstrates anti-proliferative effects on various types of tumor. In the present study, the cytotoxicity of 2-Cl-IB-MECA was analyzed in a panel of tumor and non-tumor cell lines and its anticancer mechanisms in JoPaca-1 pancreatic and Hep-3B hepatocellular carcinoma cell lines were also investigated. Initially, decreased tumor cell proliferation, cell accumulation in the $G_{1}$ phase and inhibition of DNA and RNA
\end{abstract}

Correspondence to: Dr Petr Dzubak, Institute of Molecular and Translational Medicine, Faculty of Medicine and Dentistry, Palacky University Olomouc, Hnevotinska 1333/5, 77900 Olomouc, Czech Republic

E-mail: petr.dzubak@upol.cz

Abbreviations: 2-Cl-IB-MECA， 2-chloro-N6-(3-iodobenzyl)-5'$\mathrm{N}$-methylcarboxamidoadenosine; 5-FU, fluorouracil; A3AR, A3 adenosine receptor; AdoR, adenosine receptor; AUC, area under the curve; BrdU, 5-bromo-2'-deoxyuridine; BrU, 5-bromouridine; CI, combination index; EMEM, Eagle's minimum essential medium; EMT, epithelial-mesenchymal transition; FA, fraction affected; Gli1, glioma-associated oncogene homolog zinc finger protein 1; GPCR, $\mathrm{G}$ protein-coupled receptor; $\mathrm{HCC}$, hepatocellular carcinoma; Hh, hedgehog; IB-MECA, N(6)-(3-iodobenzyl)-5'-N-methylcarboxamidoadenosine; IMDM, Iscove's modified Dulbecco's medium; LRP, lung resistance protein; MDR, multidrug resistance; MFI, median fluorescence intensity; MRP1, multidrug resistance-associated protein 1; MRS 1220 , $\mathrm{N}$-[9-Chloro-2-(2-furanyl)[1,2,4]-triazolo[1,5-c]quinazolin-5-yl]benzene acetamide; NECA, 5'-N-ethylcarboxamidoadenosine; NP-40, nonyl phenoxypolyethoxylethanol; P-gp, P-glycoprotein; pH3, phosphorylated histone H3; PMS, phenazine methosulfate; Ptch1, patched 1; RFU, relative fluorescence units; Shh, Sonic hedgehog; SMO, smoothened; TCF/LEF, $\mathrm{T}$ cell factor/lymphoid enhancer factor

Key words: 2-Cl-IB-MECA, adenosine A3 receptor, pancreatic carcinoma, hepatocellular carcinoma, multidrug resistance, chemosensitivity synthesis was found. Furthermore, western blot analysis showed decreased protein expression level of $\beta$-catenin, patched1 (Ptch1) and glioma-associated oncogene homolog zinc finger protein 1 (Gli1), which are components of the Wnt/ $\beta$-catenin and Sonic hedgehog/Ptch/Gli transduction pathways. In concordance with these findings, the protein expression levels of cyclin D1 and c-Myc were reduced. Using a luciferase assay, it was revealed for the first time a decrease in $\beta$-catenin transcriptional activity, as an early event following 2-Cl-IB-MECA treatment. In addition, the protein expression levels of multidrug resistance-associated protein 1 and $\mathrm{P}$-glycoprotein $(\mathrm{P}-\mathrm{gp}$ ) were reduced and the P-gp xenobiotic efflux function was also reduced. Next, the enhancing effects of 2-Cl-IB-MECA on the cytotoxicity of conventional chemotherapy was investigated. It was found that 2-Cl-IB-MECA enhanced carboplatin and doxorubicin cytotoxic effects in the JoPaca-1 and Hep-3B cell lines, and a greater synergy was found in the highly tumorigenic JoPaca-1 cell line. This provides a novel in vitro rationale for the utilization of 2-Cl-IB-MECA in combination with chemotherapeutic agents, not only for hepatocellular carcinoma, but also for pancreatic cancer. Other currently used conventional chemotherapeutics, fluorouracil and gemcitabine, showed synergy only when combined with high doses of 2-Cl-IB-MECA. Notably, experiments with $\mathrm{A}_{3} \mathrm{AR}$-specific antagonist, $\mathrm{N}$-[9-Chloro-2-(2-furanyl)(1,2,4)-triazolo(1,5-c)quinazolin-5-yl] benzene acetamide, revealed that 2-Cl-IB-MECA had antitumor effects via both $\mathrm{A}_{3} \mathrm{AR}$-dependent and -independent pathways. In conclusion, the present study identified novel antitumor mechanisms of 2-Cl-IB-MECA in pancreatic and hepatocellular carcinoma in vitro that further underscores the importance of $\mathrm{A}_{3} \mathrm{AR}$ agonists in cancer therapy.

\section{Introduction}

Pancreatic cancer is recognized as one of the most prevalent malignancies, with an increasing incidence rate worldwide (4.9 per 100.00 person/years, in 2020) (1). In addition to hereditary risk factors leading to the development of pancreatic cancer, there are environmental factors, such as tobacco use, alcohol consumption, chronic pancreatitis, obesity and diabetes mellitus. Furthermore, the lack of feasible screening 
tests and the asymptomatic early stage complicates the detection of the disease and decreases the survival rate (the 7 th leading cause of cancer death, data from 2018) (2).

Similar to pancreatic cancer, the incidence rate of hepatocellular carcinoma (HCC) is among the highest (9.5 per 100.000 person/years in 2020); however, it differs in different regions of the world (Western Europe, 5.4 per 100.000 person/years), with most cases in Eastern Asia (17.8 per 100.000 person/years) (1). In addition to ethnicity, important risk factors are cirrhosis, chronic hepatitis infections and an unhealthy lifestyle (3). Furthermore, both pancreatic cancer and HCC are characterized by frequent chemoresistance, which is associated with unfavorable prognoses $(4,5)$. The development of chemoresistance mechanisms are particularly important in patients with HCC and unresectable tumors, where chemotherapy remains the first choice of treatment (6-8). Due to the limited treatment options, there is a high requirement for new therapeutic agents, which has not been met.

The adenosine receptor (AdoR) family of $G$ protein-coupled receptors (GPCRs) were identified as key modulators of myocardial and neuronal cell functions, immune system, and as regulators of carcinogenesis $(9,10)$. The $A_{3}$ adenosine receptor subtype $\left(A_{3} A R\right)$ is highly expressed in tumor tissue, including pancreatic cancer and $\mathrm{HCC}$ (11-13); therefore, $\mathrm{A}_{3} \mathrm{AR}$ is a promising target for anticancer therapy. $\mathrm{A}_{3} \mathrm{AR}$ was also found to be a prognostic tumor marker in colorectal cancer by Gessi et al (14).

The first highly selective $\mathrm{A}_{3} \mathrm{AR}$ agonist, 2-chloro-N6-(3-iodobenzyl)-5'-N-methylcarboxamidoadenosine (2-Cl-IB-MECA), was synthesized more than two decades ago (15). Initially, 2-Cl-IB-MECA-mediated cardiovascular effects were demonstrated in rats (16) then, 2-Cl-IB-MECA was recognized as a neuromodulator (17), a cardio-protectant (18), a pain reliever (19), an anti-inflammatory agent (20), an immuno-modulatory agent (21), and an anticancer agent (22).

Presently, 2-Cl-IB-MECA is undergoing clinical trials for treating non-alcoholic steatohepatitis (NASH) and $\mathrm{HCC}$, showing no dose-limiting toxicity or serious drug-related side effects, while being well tolerated by patients $(23,24)$, and also showing an improvement in moderate hepatic dysfunction $(25,26)$. Another $\mathrm{A}_{3} \mathrm{AR}$ agonist, N(6)-(3-iodobenzyl)-5'-N-methylcarboxamidoadenosine (IB-MECA), successfully passed Phase III clinical trials for treating psoriasis with promising results (27), and a follow-up Phase III clinical trial for treating moderate-to-severe plaque psoriasis is currently recruiting patients (NCT03168256). Currently, 2-Cl-IB-MECA is used as a reference $\mathrm{A}_{3} \mathrm{AR}$ for both in vitro (28) and in vivo studies (29) and new N6-derivatized analogues are being developed $(30,31)$. In addition, novel avenues of GPCR signaling are emerging, such as biased agonism, allostery and receptor oligomerization $(32,33)$. These observations indicate that adenosine analogues and 2-Cl-IB-MECA are particularly useful pharmacological tools in both experimental and clinical settings.

The therapeutic potential of 2-Cl-IB-MECA in the human JoPaca-1 pancreatic cancer and the Hep-3B HCC cell lines was investigated in the present study. The JoPaca-1 cell line, established in 2012, is strongly tumorigenic and manifests a highly aggressive heterogenic phenotype, that is similar to primary pancreatic tumors (34). Notably, adenosine signaling in pancreas pathologies is surprisingly understudied (35). The Hep-3B HCC cell line is also tumorigenic, expressing mesenchymal proteins that are associated with epithelial-mesenchymal transition (EMT) and is notably responsive to Smoothened (SMO) antagonists targeting the Hedgehog pathway (Hh) (36). Adenosinergic signaling was found to be a relevant anticancer mechanism against resistant tumors in vitro $(37,38)$ and in vivo (39). Furthermore, an increasing number of studies demonstrated the effectiveness of 2-Cl-IB-MECA in resistant tumor types (40-42). In addition, the modulatory role of 2-Cl-IB-MECA in P-glycoprotein (P-gp) chemoresistance in leukemia cells (43) and the interaction of novel $\mathrm{A}_{3} \mathrm{AR}$ agonists with P-gp (44) have been found.

As a result, the ability of 2-Cl-IB-MECA to induce cytotoxicity in tumor cells; to effect the PI3K/AKT/NF- $\kappa \mathrm{B}$, Wnt/ß-catenin, and Sonic hedgehog (Shh)/Patched (Ptch)/ Glioma-associated oncogene homolog zinc finger protein (Gli) signaling pathways; to modulate the expression and function of the multidrug-resistance-associated protein 1 (MRP1) and P-gp multi-drug transporters; and to enhance the cytotoxic effects of conventional chemotherapeutic drugs in JoPaca-1 pancreatic and Hep-3B HCC cancer cell lines was investigated in the present study. In addition, a specific $\mathrm{A}_{3} \mathrm{AR}$ antagonist, $N$-[9-Chloro-2-(2-furanyl)(1,2,4)-triazolo(1,5-c) quinazolin-5-yl]benzene acetamide (MRS 1220) was used to distinguish between $\mathrm{A}_{3} \mathrm{AR}$-dependent and $\mathrm{A}_{3} \mathrm{AR}$-independent effects. Such knowledge could lead to the selection of suitable patient cohorts and maximization of their benefits from the therapy.

\section{Materials and methods}

Materials. The reagents and chemicals were purchased as follows: MRS 1220 (Tocris Bioscience); 0.9\% w/v sodium chloride intravenous infusion (B. Braun Melsungen AG); GlutaMAX $^{\mathrm{TM}}$, TrypLE $^{\mathrm{TM}}$ Express Enzyme (Thermo Fisher Scientific, Inc.), Geneticin, Zeocin Selection Reagent (Gibco; Thermo Fisher Scientific, Inc.), Pierce ${ }^{\mathrm{TM}}$ BCA Protein Assay kit and Ham's F-12K (Kaighn's) medium (Thermo Fisher Scientific, Inc.); Iscove's modified Dulbecco's medium (IMDM), Eagle's minimum essential medium (EMEM) and RPMI-1640, McCoy's 5A modified medium (Lonza Group Ltd.); Ham's F12 and DMEM/F-12 (HyClone; Cytiva); ethanol (VWR International, LLC); Cell wash reagent, Permeabilizing solution 2 and $\mathrm{Fc}$ receptor saturation reagent (BD Biosciences); FBS (Capricorn Scientific GmbH); Coelenterazine h (Biotium, Inc.); CellTiter 96 AQueous Non-Radioactive Cell Proliferation Assay (Promega Corporation); paraformaldehyde (Merck KGaA); glycine (AMSBIO LLC); Amersham ${ }^{\text {TM }}$ ECL $^{\text {TM }}$ Prime Western blotting detection reagent and Amersham nitrocellulose membrane $0.2 \mu \mathrm{M}$ (Cytiva); Britelite plus Luminescence Reporter Gene Assay System (PerkinElmer, Inc.); fluorouracil (5-FU) and gemcitabine (Accord Healthcare Ltd.); carboplatin (Fresenius Kabi Asia-Pacific, Ltd.); doxorubicin (Pharmagen $\mathrm{GmbH})$; 5'-N-ethylcarboxamidoadenosine (NECA), 2-Cl-IB-MECA, dimethyl sulfoxide (DMSO), BSA, EDTA, PI, 5-Bromo-2'-deoxyuridine (BrdU), 5-Bromouridine (BrU), sodium tetraborate decahydrate, nonyl phenoxypolyethoxylethanol (NP-40), RNase A, Fraction V, daunorubicin, puromycin and all other chemicals were purchased from Sigma-Aldrich 
(Merck KGaA). All compounds used for treatments were of $\geq 98 \%$ purity. For all experiments, DMSO was used as vehicle for MRS 1220, NECA and 2-Cl-IB-MECA, while $0.9 \% \mathrm{w} / \mathrm{v}$ sodium chloride intravenous infusion was used as a vehicle for 5-FU, gemcitabine, carboplatin and doxorubicin.

The following primary antibodies were used: $A_{3} A R$ (cat. no. ab203298; 1:500), phosphorylated pAKT Ser ${ }^{473}$ (cat. no. ab192623; 1:500), pAKT Thr ${ }^{308}$ (cat. no. ab38449; $1: 500), \mathrm{NF}-\kappa \mathrm{B}$ (cat. no. ab16502; 1:1,000), $\beta$-catenin (cat. no. ab32572; 1:2,500), Gli1 (cat. no. ab134906; 1:500), Ptch1 (cat. no. ab53715; 1:1,000), c-Myc (cat. no. ab32072; 1:1,000) all from Abcam; ERK1/2 (cat. no. 9102; 1:1,000), pERK1/2 $\mathrm{Thr}^{202} / \mathrm{Tyr}^{204}$ (cat. no. 20G11; 1:1,000), AKT (cat. no. 9272S; 1:1,000), pNF-кB Ser ${ }^{536}$ (cat. no. 3033; 1:1,000), GSK-3b (cat. no. 27C10; 1:1,000), pGSK-3b $\operatorname{Ser}^{9}$ (cat. no. 9336; 1:1,000), cyclin D1 (cat. no. 2978; 1:500), pc-Myc Ser ${ }^{62}$ (cat. no. 13748S; 1:1,000), pc-Myc $\mathrm{Thr}^{58}$ (cat. no. 46650S; 1:1,000) from Cell Signaling Technology, Inc.; MRP1 (cat. no. 801-012-C250; 1:250) from Enzo Life Sciences, Inc.; p-histone H3 Ser ${ }^{10}$ (cat. no. 06-570; $1: 500$ ) from Merck KGaA; $\beta$-actin (cat. no. A2228; 1:3,000), IgG1 isotype control unconjugated (cat. no. M5284; 1:140), P-gp (cat. no. P7965; 1:250) from Sigma-Aldrich (Merck $\mathrm{KGaA}$ ); and anti-BrdU (cat. no. 11-286-C025; 1:250) from EXBIO Praha, a.s. Secondary antibodies conjugated with HRP anti-rabbit IgG (cat. no. A-0545; 1:10,000) and anti-mouse IgG (cat. no. A-2304; 1:10,000), and anti-mouse-IgG-FITC (cat. no. F2883; 1:250) were purchased from Sigma-Aldrich (Merck KGaA). Anti-rabbit-IgG-Alexa Fluor 488 (cat. no. A-11070; 1:500) was purchased from Thermo Fisher Scientific, Inc.

The JoPaca-1 pancreatic carcinoma and Hep-3B HCC cell lines were purchased from German Collection of Microorganisms and Cell Cultures. The A549 lung carcinoma, BJ non-tumor fibroblast, BT-549 and MDA-MB-231 breast cancer, CCRF-CEM leukemia, non-tumor MRC-5 fibroblast, U2OS osteosarcoma, HCT116 colon carcinoma and HT-29 colorectal cancer cell lines were purchased from the American Type Culture Collection. The human ES-012-A $\mathrm{A}_{3} \mathrm{AR}$ aequorin cell line was purchased from Perkin Elmer, Inc., while the parental K562 leukemia and the HCT116

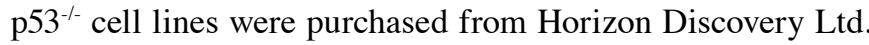
The CEM-DNR (resistant to daunorubicin) and K562-TAX (resistant to paclitaxel) cell lines were established in our laboratory (45).

The $\beta$-catenin reporter cell lines were prepared as follows: The U2OS, HCT 116 and HT-29 cell lines were stably transduced at multiplicity of infection, 5 , at $37^{\circ} \mathrm{C}$ for $16 \mathrm{~h}$ with commercially available lentiviral particles [Cignal Lenti $\mathrm{T}$ cell factor/lymphoid enhancer factor (TCF/LEF) Reporter Assays; cat. no. CLS-018L; Qiagen $\mathrm{GmbH}$ ] carrying the TCF/LEF responsive element coupled to firefly luciferase reporter gene. The following three models of the $\mathrm{Wnt} / \beta$-catenin pathway were established using antibiotic selection in the presence of $1 \mu \mathrm{g} / \mathrm{ml}$ puromycin: Wild-type (derived from the U2OS cell line; $\beta$-catenin ${ }^{\mathrm{WT}}$ ); constitutively active with deletion of $\mathrm{Ser}^{45}$ in $\beta$-catenin, where this single nucleotide variant prevents $\beta$-catenin proteasomal degradation (derived from the HCT116 cell line; $\beta$-catenin ${ }^{\text {mut }}$ ); and constitutively active with a loss-of-function mutation in the APC gene (derived from the HT-29 cell line; APC ${ }^{\text {mut }}$ ). Monoclonal cell lines were generated from polyclonal population after one-week selection in presence of $1 \mu \mathrm{g} / \mathrm{ml}$ puromycin using single cell sorting (FACSAria II SORP; BD Biosciences) and maintained in the corresponding media containing $1 \mu \mathrm{g} / \mathrm{ml}$ puromycin. Before the experiments, specific reporter activity for each clonal cell line was verified by stimulation with the Wnt3a ligand and small interfering (si)RNA-mediated downregulation of $\beta$-catenin. The experiments were conducted within one month from the transduction.

Cell culture. The cell lines were maintained and sub-cultured according to manufacturer's instructions under the following conditions: JoPaca-1 (IMDM; 20\% FBS); K562 (IMDM; 10\% FBS); Hep-3B (EMEM; 10\% FBS; GlutaMAX ${ }^{\mathrm{TM}}$ ); MRC-5 and BJ (EMEM; 10\% FBS); K562-TAX, CCRF-CEM, CEM-DNR, BT-549 and MDA-MB-231 (RPMI-1640; 10\% FBS); A549 (Ham's F-12K; 10\% FBS); HCT116 and HCT116 $\mathrm{p} 53^{-/-}$(RPMI; 10\% FBS); U2OS and HT-29 (McCoy's 5A modified medium; 10\% FBS); $\mathrm{A}_{3} \mathrm{AR}$ reporter ES-012-A (Ham's F-12; $10 \%$ FBS; GlutaMAX ${ }^{\mathrm{TM}} ; 0.4 \mathrm{mg} / \mathrm{ml}$ geneticin; and $0.25 \mathrm{mg} / \mathrm{ml}$ zeocin); $\beta$-catenin reporter cell lines (McCoy's 5A modified medium; $10 \% \mathrm{FBS} ; 1 \mu \mathrm{g} / \mathrm{ml}$ puromycin). The cell lines were authenticated using short tandem repeat DNA profiling analysis (PowerPlex 18D; Promega Corporation), analyzed every two weeks for mycoplasma contamination (reverse transcription-quantitative PCR), and maintained in $\mathrm{T}-150$ flasks at $37^{\circ} \mathrm{C}$ in a humidified incubator with $5 \% \mathrm{CO}_{2}$ and $100 \%$ humidity. For the experiments, the cells were placed in fresh medium, with no antibiotics at densities specified for each method.

$A_{3} A R$ functional assay. The $\mathrm{A}_{3} \mathrm{AR}$ functional assay used was performed as previously described (46) with modifications. Briefly, ES-012-A is an AequoScreen reporter cell line stably expressing $\mathrm{A}_{3} \mathrm{AR}$, the photoprotein aequorin, and the promiscuous Ga16 protein subunit. The ES-012-A cell line was non-enzymatically harvested with PBS/EDTA and incubated in DMEM/F12 medium with $5 \mu \mathrm{M}$ coelenterazine for $4 \mathrm{~h}$ at room temperature (RT) in the dark to reconstitute the active form of aequorin. Meanwhile, 384-well microplates with pre-diluted 2-Cl-IB-MECA (50 $\mu \mathrm{M}-1 \mathrm{pM})$ and MRS $1220(10 \mu \mathrm{M}-0.01 \mathrm{pM})$ were prepared using the acoustic liquid handler ECHO 550 (LabCyte, Inc.).

Coelenterazine-loaded cells $\left(5 \times 10^{3}\right.$ cells per well) were dispensed using a cell suspension system and the FLIPR tetra multimodal reader (Molecular Devices, LLC.). The resulting luminescence was recorded immediately. The cells were incubated within the instrument for another $15 \mathrm{~min}$ at RT and the antagonistic response, represented by a drop in luminescence signal, was measured directly after the addition of the reference agonist NECA, at $80 \%$ of maximal effective concentration $\left(\mathrm{EC}_{80}\right)$. Raw data (area under the curve; AUC) were normalized to the percentage of the reference agonist NECA response (arbitrarily set at 100\%). Normalized response in percentage was plotted against concentration, and $\mathrm{EC}_{50}$ (for agonist) and $\mathrm{IC}_{50}$ (for antagonist) were calculated. The data used for analysis were the result of four independent experiments.

Cytotoxicity assay. The cytotoxicity assay was performed as previously described (47). Briefly, the cell lines were seeded into 384-well microplates, at specific densities for each cell 
line $\left(0.9-2.5 \times 10^{3}\right.$ cells per well). After $24 \mathrm{~h}$, all the tested compounds were added to the microplates using the acoustic liquid handler ECHO 550. Either vehicle, 2-Cl-IB-MECA, MRS 1220 or 2-Cl-IB-MECA in combination with $0.1 \mu \mathrm{M}$ fixed concentration of MRS 1220 were analyzed at a concentration range 100-0.2 $\mu \mathrm{M}$ in the JoPaca-1 and Hep-3B cell lines. The vehicle volume was equal to the maximal concentration of treatment. In the other tumor and non-tumor cell lines, 2-Cl-IB-MECA was analyzed at 0.02-50 $\mu \mathrm{M}$.

In the $\beta$-catenin reporter cell lines, 2-Cl-IB-MECA was analyzed at a single concentration of $50 \mu \mathrm{M}$. In the synergy combination experiments, 2-Cl-IB-MECA was analyzed at a concentration range from 1.56 to $50 \mu \mathrm{M}$ in the JoPaca-1 cell line and from 0.78 to $25 \mu \mathrm{M}$ in the Hep-3B cell line. The chemotherapeutic agents were used at concentrations as follows: 5-FU and carboplatin $(0.78-200 \mu \mathrm{M})$, doxorubicin $(0.1-25 \mu \mathrm{M})$, gemcitabine $(0.2-50 \mu \mathrm{M})$. For the 2-Cl-IB-MECA and MRS 1220 combination experiments, MRS 1220 was added to the cells $30 \mathrm{~min}$ prior to 2-Cl-IB-MECA.

The treated cells were incubated at $37^{\circ} \mathrm{C}$ with $5 \% \mathrm{CO}_{2}$ and $100 \%$ humidity for 24 and $48 \mathrm{~h}$ ( $\beta$-catenin reporters) or $72 \mathrm{~h}$ (other cell lines). After incubation, MTS solution and phenazine methosulfate (PMS), an electron coupling reagent, was prepared according to manufacturer's instructions and dispensed to the microplates using a Multidrop Combi reagent dispenser (Thermo Fisher Scientific, Inc.). The final concentration of MTS/PMS in the wells was $235 \mu \mathrm{g} / \mathrm{ml}$. All the cell lines were allowed to metabolize the MTS/PMS reagent into formazan for $1.5-3 \mathrm{~h}$ at $37^{\circ} \mathrm{C}$ with $5 \% \mathrm{CO}_{2}$ and $100 \%$ humidity. Absorbance of the formazan product was measured at $490 \mathrm{~nm}$ using an EnVision plate reader (Perkin Elmer, Inc.) and, after subtracting the blank, the cytotoxic (anti-proliferative) effects were expressed as percentage of inhibition. The data used for analysis were the result of three independent experiments.

For the enhanced effect of combined treatments in synergy experiments, the effects were expressed as the fraction affected (FA) normalized to cells treated with vehicle (DMSO for 2-Cl-IB-MECA and MRS 1220;0.9\% w/v sodium chloride intravenous infusion for chemotherapeutic agents), and was calculated using the following equation: $\mathrm{FA}=1$-(sample-blank/control-blank), where the sample is the value from a single well treated with a compound, the control is the average absorbance of the cells treated with vehicle and the blank is the average absorbance of the background without cells.

The effects of two drug treatments were assessed using the CalcuSyn software (version 2.0; Biosoft), as a combination index $(\mathrm{CI})$ and the Chou-Talalay method $(48,49)$. The FA was used as data input, where $\mathrm{CI}<0.9$ was quantitatively defined as synergism, $\mathrm{CI}>0.9$ and $<1.1$ as an additive effect, and CI $>1.1$ as antagonism.

Cell cycle analysis. Cell cycle analysis was performed as previously described (50). The JoPaca-1 and Hep-3B cell lines were seeded $24 \mathrm{~h}$ before treatment in 6-well multi dishes, at 2.7- and $2.2 \times 10^{5}$ cells per well, respectively. The JoPaca-1 and Hep-3B cells were treated for $24 \mathrm{~h}$ with either vehicle, $20 \mathrm{nM}$ or $20 \mu \mathrm{M}$ 2-Cl-IB-MECA using the ECHO 550 dispenser. Both adherent and detached cell fractions were subsequently harvested using TrypLE reagent on ice, washed with PBS, fixed with $70 \%$ ethanol at $-20^{\circ} \mathrm{C}$ added drop by drop, and immediately transferred to $-20^{\circ} \mathrm{C}$ for another $24 \mathrm{~h}$. The fixed cells were washed with citrate buffer to enhance extraction of the fragmented DNA (the subG ${ }_{1}$ population), stained with $600 \mu \mathrm{lPI}(50 \mu \mathrm{g} / \mathrm{ml})$ for $30 \mathrm{~min}$ at $37^{\circ} \mathrm{C}$ in the dark, followed by incubation of samples with added $500 \mu \mathrm{l}$ RNAse $(2 \mathrm{mg} / \mathrm{ml})$ for another 15 min under the same conditions. Before adding PI, half of each sample was separated and incubated for $1 \mathrm{~h}$ with an antibody against p-histone $\mathrm{H} 3 \mathrm{Ser}^{10}(\mathrm{pH} 3)$ at $\mathrm{RT}$ in the dark The samples were washed with PBS containing $1 \%$ FBS, then incubated with fluorescent secondary antibody, Alexa Fluor 488 for another $30 \mathrm{~min}$ at RT in the dark, washed with PBS containing $1 \%$ FBS and stained with PI as aforementioned.

PI and Alexa Fluor 488 fluorescence intensities in relative fluorescence units (RFU) were then measured using a flow cytometer (FACS Calibur; BD Imunocytometry Systems) with a $488 \mathrm{~nm}$ single beam argon laser, with two types of settings for fluorescence measurement of PI (linear for cell cycle and $\mathrm{pH} 3$ and logarithmic for subG ${ }_{1}$ ). Analysis of the cell cycle phases was performed using ModFit LT (version 2.0; Verity Software House, Inc.) and quantifications of the $\mathrm{subG}_{1}$ and pH3-marked mitotic cells were performed using CellQuest software (version 3.3; BD Immunocytometry Systems). Each sample consisted of at least $1 \times 10^{4}$ cells in compliance with the required parameters from three independent experiments.

DNA synthesis. The level of DNA synthesis was quantified by incorporating BrdU into the DNA from the JoPaca-1 and Hep-3B cell lines according to a previous study (50). Briefly, the cells were seeded $24 \mathrm{~h}$ before treatment in 6-well multi dishes at $2.7 \times 10^{5}$ and $2.2 \times 10^{5}$ cells per well for the JoPaca-1 and Hep-3B cells, respectively, to achieve an approximate density of $60 \%$ at the time of treatment. The cell lines were treated with either vehicle, $20 \mathrm{nM}$ or $20 \mu \mathrm{M}$ 2-Cl-IB-MECA, or with the combination of 2-Cl-IB-MECA ( $20 \mathrm{nM}$ or $20 \mu \mathrm{M})$ and MRS $1220(0.1 \mu \mathrm{M})$ for $24 \mathrm{~h}$, for the JoPaca- 1 and Hep-3B cells, respectively. For the combination experiments, MRS 1220 was added to the cells $30 \mathrm{~min}$ before 2-Cl-IB-MECA. The cells were then labelled with $1 \mu \mathrm{M} \mathrm{BrdU}$ solution at $37^{\circ} \mathrm{C}$ with $5 \% \mathrm{CO}_{2}$ and $100 \%$ humidity for $60 \mathrm{~min}$ before harvesting.

The cells were harvested with TrypLE reagent, washed with PBS, fixed with $70 \%$ ethanol at $-20^{\circ} \mathrm{C}$, added dropwise and immediately transferred to $-20^{\circ} \mathrm{C}$ for $24 \mathrm{~h}$. The samples were then incubated with $2 \mathrm{M} \mathrm{HCl} /$ Triton X-100 solution for $30 \mathrm{~min}$ at RT. The DNA denaturing reaction was neutralized with $0.1 \mathrm{M}$ sodium tetraborate decahydrate. The cells were then washed with PBS containing $1 \%$ BSA and $0.5 \%$ Tween-20 and stained with primary anti-BrdU antibody for $30 \mathrm{~min}$ at RT in the dark. After washing with PBS, the cells were incubated with secondary anti-mouse-IgG-FITC antibody for $30 \mathrm{~min}$ at $\mathrm{RT}$ in the dark. The stained samples were washed with PBS one last time and incubated with $0.5 \mathrm{mg} / \mathrm{m}$ RNAse A for $15 \mathrm{~min}$, followed by $0.1 \mathrm{mg} / \mathrm{ml}$ PI for another $15 \mathrm{~min}$ both at RT in the dark.

The samples were measured using a FACSCalibur flow cytometer and a $488 \mathrm{~nm}$ argon laser. Each sample included at least $1 \times 10^{4}$ cells in compliance with the required parameters from three independent experiments. The rate of DNA synthesis was analyzed using CellQuest software (version 3.3; BD Immunocytometry Systems). 
RNA synthesis. RNA synthesis was quantified by incorporating BrU into RNA in the JoPaca-1 and Hep-3B cell lines according to a previous study (50). In short, the cells were seeded $24 \mathrm{~h}$ before treatment in 6 -well multi dishes at $2.7 \times 10^{5}$ and $2.2 \times 10^{5}$ cells per well for the JoPaca- 1 and Hep-3B cell lines, respectively, to achieve $\sim 60 \%$ density at the time of treatment. The concentrations and combinations of the compounds added to the cells were identical to the DNA synthesis experiment, as aforementioned. The cells were incubated for $24 \mathrm{~h}$. Before harvesting, the cells were labelled with $1.5 \mu \mathrm{M}$ BrU solution for $90 \mathrm{~min}$ at $37^{\circ} \mathrm{C}$ with $5 \% \mathrm{CO}_{2}$ and $100 \%$ humidity. The cells were harvested using TrypLE reagent followed by fixation in $1 \%$ paraformaldehyde, with $0.05 \% \mathrm{NP}-40$ in PBS for $15 \mathrm{~min}$ on a rotating wheel at RT. The samples were stored overnight at $4^{\circ} \mathrm{C}$. Subsequently, the cells were washed with PBS, containing $1 \%$ glycine, with PBS alone, then stained with unconjugated anti-BrdU antibody for $45 \mathrm{~min}$ at RT, which cross-reacts with the $\mathrm{BrU}$ incorporated into the cells. After washing again with PBS containing $0.1 \%$ NP-40 and $0.1 \%$ BSA, the cell suspension was fluorescently labelled by incubation with secondary anti-mouse-IgG-FITC antibody for $30 \mathrm{~min}$ at RT in the dark. The labelled samples were washed with PBS containing $0.1 \%$ NP-40 and $0.1 \%$ BSA and fixed with $1 \%$ paraformaldehyde and $0.05 \%$ NP-40 in PBS for $15 \mathrm{~min}$ at RT in the dark and, subsequently, incubated for $1 \mathrm{~h}$ at $4^{\circ} \mathrm{C}$. After the last wash with PBS, the cells were incubated with $0.5 \mathrm{mg} / \mathrm{ml}$ RNAse A for $15 \mathrm{~min}$ at RT, followed by $0.1 \mathrm{mg} / \mathrm{ml} \mathrm{PI}$ for another $15 \mathrm{~min}$ at RT in the dark. BrU-labelled samples were analyzed as previously described for DNA staining and the data used was from three independent experiments.

Western blot analysis. The JoPaca-1 and Hep-3B cell lines were seeded in 6-well multi dishes, at densities of $2.7 \times 10^{5}$ and $2.2 \times 10^{5}$ cells, respectively, and treated with either vehicle $(24 \mathrm{~h})$, $20 \mu \mathrm{M}$ 2-Cl-IB-MECA, or $0.1 \mu \mathrm{M}$ MRS 1220 for $30 \mathrm{~min}$ prior to 2-Cl-IB-MECA, for 24 and $48 \mathrm{~h}$. The cells were harvested on ice using a scraper and lysed with ice-cold RIPA buffer $(150 \mu \mathrm{M} \mathrm{NaCl}, 1 \% \mathrm{NP}-40,0.5 \%$ sodium deoxycholate, $0.1 \%$ SDS, $50 \mu \mathrm{M}$ Tris- $\mathrm{HCl} \mathrm{pH} 8.0$ and $1 \mu \mathrm{M}$ EDTA) for $30 \mathrm{~min}$, then sonicated at $35 \mathrm{kHz}$ for $1 \mathrm{~min}$ in a $4^{\circ} \mathrm{C}$ ultrasonic water bath. Next, the cell debris were discarded using centrifugation at $14,000 \mathrm{x} \mathrm{g}$ for $15 \mathrm{~min}$ at $4^{\circ} \mathrm{C}$. The protein concentrations were determined using a BCA protein assay. After $5 \mathrm{X}$ concentrated Laemmli buffer was added, the protein samples were incubated at $70^{\circ} \mathrm{C}$ for $10 \mathrm{~min}$. Equal concentrations $(20 \mu \mathrm{g})$ of each sample were separated using 7.5 or $12 \%$ SDS-PAGE. The resolved proteins were transferred to nitrocellulose membranes using the semi-dry blot method (Trans-Blot Turbo Transfer System; Bio-Rad Laboratories, Inc.). The membranes were blocked with 5\% BSA in TBS, containing 0.1\% Tween-20 for $1 \mathrm{~h}$ at RT, then incubated overnight at $4^{\circ} \mathrm{C}$ with the primary antibodies. Subsequently, the membranes were washed in TBS, containing $0.1 \%$ Tween-20 and incubated for $1 \mathrm{~h}$ at RT with HRP anti-rabbit IgG or anti-mouse IgG secondary antibodies. Next, the proteins were visualized using ECL substrate and a ChemiDoc MP Imaging System (Bio-Rad Laboratories, Inc.). The immunoblot images were processed using Image Lab v6.1 (Bio-Rad Laboratories, Inc.) and, if relevant, band densities were analyzed using ImageJ software (51). Relative intensities were calculated using $\beta$-actin as the loading control and expressed as fold change. In the same manner, $\mathrm{A}_{3} \mathrm{AR}$ endogenous protein expression was analyzed using western blot analysis in the MRC-5, JoPaca-1 and Hep-3B cell lines. The data used for analysis were the result of three independent experiments.

$\beta$-catenin reporter assay. The $\beta$-catenin ${ }^{\mathrm{WT}}, \beta$-catenin ${ }^{\mathrm{mut}}$, and $\mathrm{APC}^{\text {mut }}$ reporter cell lines were seeded onto 384 -well microplates, at a density of $2.5 \times 10^{3}$ cells per well. After incubation for $24 \mathrm{~h}$ at $37^{\circ} \mathrm{C}$ with $5 \% \mathrm{CO}_{2}$ and $100 \%$ humidity, all analyzed compounds were added to the microplates, at the indicated concentrations as aforementioned using an acoustic liquid handler ECHO 550 and the treated cells were incubated for specific durations $(1,3,6,12,24$ and $48 \mathrm{~h})$.

Immediately after the addition of the Britelite plus reagent, the luminescence signal proportional to the transcriptional activity of the reporters was measured using an EnVision plate reader. After subtracting the blank, $\beta$-catenin transcriptional activity was calculated as a percentage of inhibition, defined similarly to the MTS assay. The data used for analysis were from three independent experiments.

P-gp expression. The JoPaca-1 and Hep-3B cell lines were seeded in 6-well multi dishes, at $2.7 \times 10^{5}$ and $2.2 \times 10^{5}$ cells per well, respectively. The cells at $\sim 60 \%$ density were treated with either vehicle or $20 \mu \mathrm{M}$ 2-Cl-IB-MECA 24 h later. After another $24 \mathrm{~h}$, the cells were collected using TrypLE reagent, centrifuged at $500 \times \mathrm{g}$ for $5 \mathrm{~min}$, at RT and the pellet was washed with PBS. The cells were fixed with cold methanol $\left(-20^{\circ} \mathrm{C} ; 100 \%\right)$, added dropwise, then the cells were stored at $-20^{\circ} \mathrm{C}$ for a minimum of $24 \mathrm{~h}$ before analysis.

Subsequently, the cells were washed with rinsing buffer, composed of Cell wash reagent, $0.5 \%$ BSA, $0.1 \%$ NP-40, then permeabilized with Permeabilizing solution 2 for $10 \mathrm{~min}$, and washed again with rinsing buffer. A saturation reagent that blocks $\mathrm{Fc}$ receptors to prevent unspecific binding of the antibody (Cell wash reagent, $0.5 \%$ BSA and Fc receptor saturation reagent) was added to the cells, then incubated for $10 \mathrm{~min}$ at RT, and washed twice more with Cell wash reagent containing $0.5 \% \mathrm{BSA}$ and $0.1 \% \mathrm{NP}-40$. The samples were divided into two tubes: One for P-gp expression analysis (monoclonal anti-P-gp antibody) and one for the isotype control (IgG1 isotype control; unconjugated); both tubes were incubated with the antibodies for $30 \mathrm{~min}$ at RT in the dark. Following which, all the samples were washed with rinsing buffer and incubated with FITC-conjugated secondary antibody anti-mouse-IgG for $30 \mathrm{~min}$ at RT, washed once more, then stored at $4^{\circ} \mathrm{C}$ for $15 \mathrm{~min}$.

Median fluorescence intensities (MFI) for both samples and isotype controls were measured with a $488 \mathrm{~nm}$ argon laser and a FACS Calibur flow cytometer, where the isotype controls defined the intensity threshold at a median of 10 relative fluorescence units. MFI raw data were the result of three independent experiments and analyzed using CellQuest (version 3.3; BD Immunocytometry Systems).

$P$-gp efflux assay. The K562-TAX cell line, derived from K562 chronic myelogenous leukemia cell line, was developed at the Institute of Molecular and Translational Medicine, as a cell line that is resistant to paclitaxel, with high expression of 
the P-gp transporter and low expression levels of MRP1 and lung resistance protein (LRP) transporters (45).

The P-gp efflux assay was conducted as previously described (52). Briefly, the K562-TAX cells were seeded in 6 -well multi dishes at $2.5 \times 10^{5}$ and allowed to proliferate for $24 \mathrm{~h}$. The next day, the cells were treated with $1 \mu \mathrm{M}$ daunorubicin (fluorescent) for $60 \mathrm{~min}$ at $37^{\circ} \mathrm{C}$ in the dark. The cells were washed twice with complete medium and incubated with 2-Cl-IB-MECA $(0.78-100 \mu \mathrm{M})$, either alone or following $0.1 \mu \mathrm{M}$ MRS 1220 pre-treatment for $30 \mathrm{~min}$ at $37^{\circ} \mathrm{C}$, for another $60 \mathrm{~min}$ under the same conditions as aforementioned. Following which, the K562-TAX cells were harvested using a scraper and fluorescence intensity was measured immediately using a FACS Calibur flow cytometer and a $488 \mathrm{~nm}$ argon laser.

Each sample comprised at least $1 \times 10^{4}$ cells, that were compliant with the required parameters. The raw data were the result of three independent experiments and were measured as MFI. MFI for the vehicle was set to 10 relative fluorescence units. MFI comparisons were analyzed using CellQuest (version 3.3; BD Immunocytometry Systems).

Statistical analysis. The results are expressed as the mean \pm SD, with the number of independent replicates (n) indicated for each experiment. Quantification of the results was performed using GraphPad Prism v9 for Windows (GraphPad Software, Inc.), including $\mathrm{IC}_{50}$ values for the JoPaca-1 and Hep-3B cell lines. The $\mathrm{IC}_{50}$ values in the MTS experiment using the other tumor and non-tumor cell lines were calculated using Dotmatics software (version 5.5; Dotmatics, Ltd.). Statistical analyses were performed using R statistical software, v3.5.0 (R Foundation for Statistical Computing; www.r-project.org). The data was checked for normality using the Shapiro-Wilk test. Statistical differences between treatment group and the reference group (vehicle) were analyzed using a Student's one-sample t-test. An unpaired Student's two-sample t-test was used for comparison of treatments. ANOVA followed by Dunn's post hoc test was used to analyze 2-Cl-IB-MECA at 24 and $48 \mathrm{~h}$ and the reference group (MRS 1220 at $24 \mathrm{~h}$ ). A one-way ANOVA test, followed by Dunn's post hoc test was used to analyze the 2-Cl-IB-MECA group at 24 and $48 \mathrm{~h}$ and the vehicle as the reference group, for phosphorylated/total protein. In case of comparison of more than two treatment conditions, ANOVA followed by Tukey's post hoc test was used. $\mathrm{P}<0.05$ was considered to indicate a statistically significant difference.

\section{Results}

2-Cl-IB-MECA shows cytotoxicity for cancer cell lines and agonistic activity on $A_{3} A R$. Previous studies have shown both pro- and antitumor effects of 2-Cl-IB-MECA in vitro and in vivo at either sub-micromolar or micromolar concentrations (reviewed in 53). To determine the overall cytotoxic ability of 2-Cl-IB-MECA (Fig. 1A), the effects of 2-Cl-IB-MECA against a panel of tumor and non-tumor cell lines was performed. Using a MTS assay, the cells were incubated with 2-Cl-IB-MECA for $72 \mathrm{~h}$ and the cellular response was analyzed using different concentrations $(0.2-100 \mu \mathrm{M}$ for the JoPaca-1 and Hep-3B cell lines and 0.02-50 $\mu \mathrm{M}$ for the other cell lines). Cytotoxicity against 2-Cl-IB-MECA was found in micromolar concentrations across various tumor cell lines, of different histogenetic origin, including JoPaca-1 and the most sensitive cell line, Hep-3B, with their respective $\mathrm{IC}_{50}$ values of $25.26 \pm 1.6$ and $10.68 \pm 1.1 \mu \mathrm{M}$ (Table I). Furthermore, the non-tumor fibroblast cell lines, MRC-5 and BJ cells remained metabolically active despite increasing 2-Cl-IB-MECA concentrations, with $\mathrm{IC}_{50}$ values $>50 \mu \mathrm{M}$.

Next, the compounds, 2-Cl-IB-MECA and MRS 1220 were both analyzed on reporter cell lines expressing $\mathrm{A}_{3} \mathrm{AR}$. The functional assay revealed $\mathrm{A}_{3} \mathrm{AR}$ activation by 2-Cl-IB-MECA $\left(\mathrm{EC}_{50}, 32.28 \pm 11.2 \mathrm{nM}\right)$, and its inhibition by MRS $1220\left(\mathrm{IC}_{50}\right.$, $1.41 \pm 0.9 \mathrm{nM}$ ) at nanomolar concentrations (Fig. 1B).

To identify whether any possible effects could be $\mathrm{A}_{3} \mathrm{AR}$ related, western blot analysis was performed to analyze $\mathrm{A}_{3} \mathrm{AR}$ protein expression (Fig. 1C). By contrast to the non-tumor MRC-5 fibroblasts, the results showed the presence of $\mathrm{A}_{3} \mathrm{AR}$ in both the JoPaca-1 and Hep-3B tumor cell lines analyzed.

To address the nature of the effects of 2-Cl-IB-MECA on human pancreatic cancer and HCC cells more precisely, the JoPaca-1 and Hep-3B cell lines were treated with increasing concentrations of 2-Cl-IB-MECA and MRS 1220 alone, and in combination for $72 \mathrm{~h}$. MRS 1220 is a specific $\mathrm{A}_{3} \mathrm{AR}$ antagonist $(54,55)$ and MRS 1220 intrinsic cytotoxicity as well as its ability to counteract the effect of the $\mathrm{A}_{3} \mathrm{AR}$ agonist 2-Cl-IB-MECA was analyzed in the cancer cells. Notably, pre-treatment of the cells with $0.1 \mu \mathrm{M}$ MRS 1220 led to significantly decreased 2-Cl-IB-MECA cytotoxicity in both cell lines. MRS 1220 alone at sub-micromolar concentrations were not cytotoxic for either cell line (Fig. 1D and E). Taken together, 2-Cl-IB-MECA inhibited the proliferation of the cancer cell lines, including JoPaca-1 and HEP-3B cancer cells at micromolar concentrations and its effect in the JoPaca-1 and HEP-3B cell lines was reduced by MRS 1220. Therefore, $20 \mathrm{nM}$ (the $\mathrm{A}_{3} \mathrm{AR}$-activating concentration) and $20 \mu \mathrm{M}$ (considerable cytotoxicity-inducing concentration) of 2-Cl-IB-MECA was used for further experiments.

2-Cl-IB-MECA downregulates cell cycle progression by increasing the number of cells in the $G_{1}$ phase and induces cell death. Previous studies showed that the N6-adenosine analogue 2-Cl-IB-MECA reduces the cell cycle in other cancer cell types, such as NPA thyroid carcinoma and A375 melanoma cells $(12,56)$. Flow cytometry analysis was performed to analyze cell cycle progression, including the $\operatorname{subG}_{1}$ population, histone $\mathrm{H} 3$ phosphorylation, and changes in RNA and DNA synthesis, to further assess a possible anticancer mechanism of 2-Cl-IB-MECA. Based on the cytotoxicity experiments, the JoPaca-1 and Hep-3B cell lines were each treated with either vehicle, $20 \mathrm{nM}$ or $20 \mu \mathrm{M}$ of 2-Cl-IB-MECA for $24 \mathrm{~h}$. In DNA and RNA synthesis experiments, the cells were pre-treated with $0.1 \mu \mathrm{M}$ MRS 1220 for 30 min prior to the addition of 2-Cl-IB-MECA.

Only $20 \mu \mathrm{M}$ 2-Cl-IB-MECA affected the cell cycle, showing an increase in the number of cells in the $G_{1}$ phase. In addition, there was a simultaneous increase in the subG $\mathrm{G}_{1}$ population, representing cells undergoing apoptosis (Fig. 2A-C). The Hep-3B cell line was more responsive compared with that in the JoPaca-1 cell line (Fig. 2B). In concordance with the block at the $G_{1}$ transition point, there was a reduction in the number of cells in $\mathrm{S}$ phase. Indeed, the reduction in the 
A<smiles>CNC(=O)[C@H]1O[C@@H](n2cnc3c(N)nc(Cl)nc32)[C@H](O)[C@@H]1O</smiles>

B

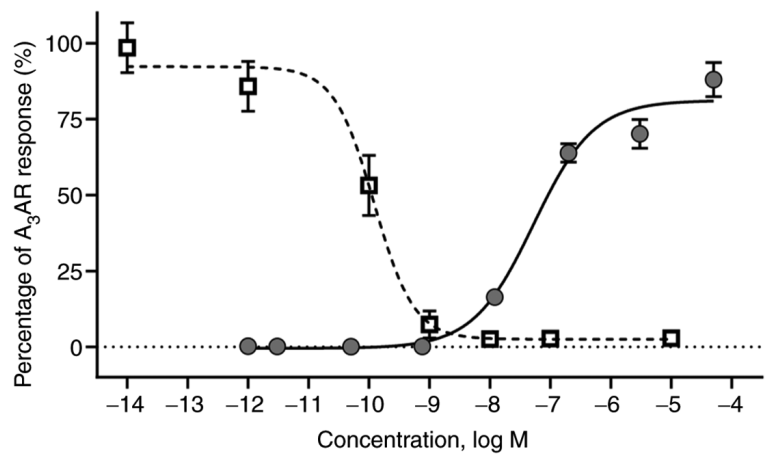

2-CI-IB-MECA $\quad \mathrm{EC}_{50}=32.28 \mathrm{nM} \pm 11.2$

ㅁ. MRS $1220 \quad \mathrm{IC}_{50}=1.41 \mathrm{nM} \pm 0.9$
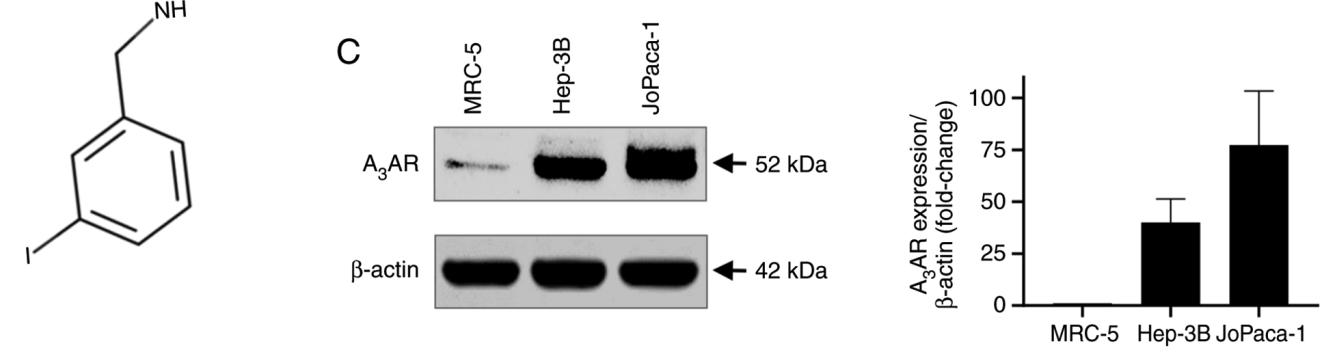

D
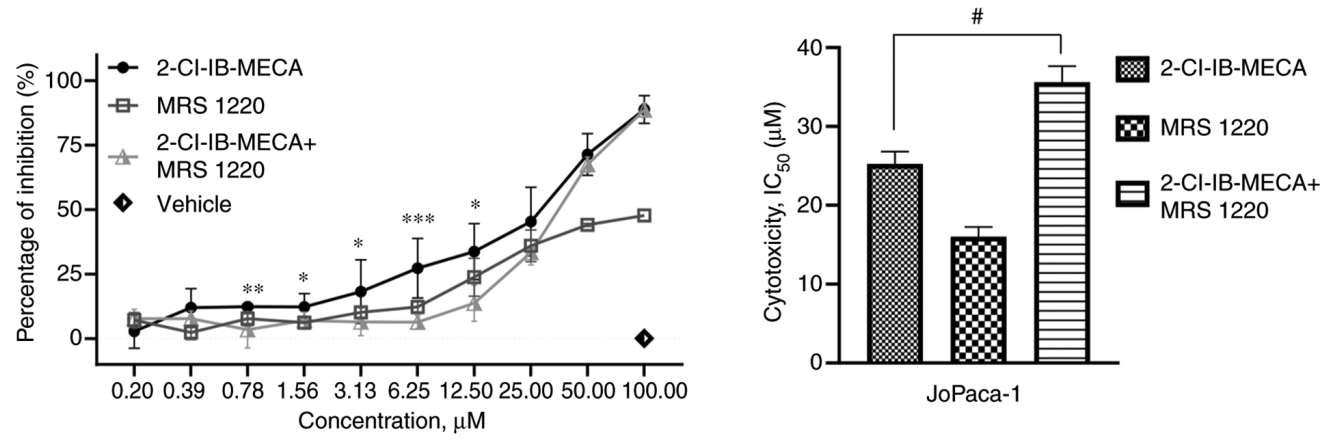

$\mathrm{E}$
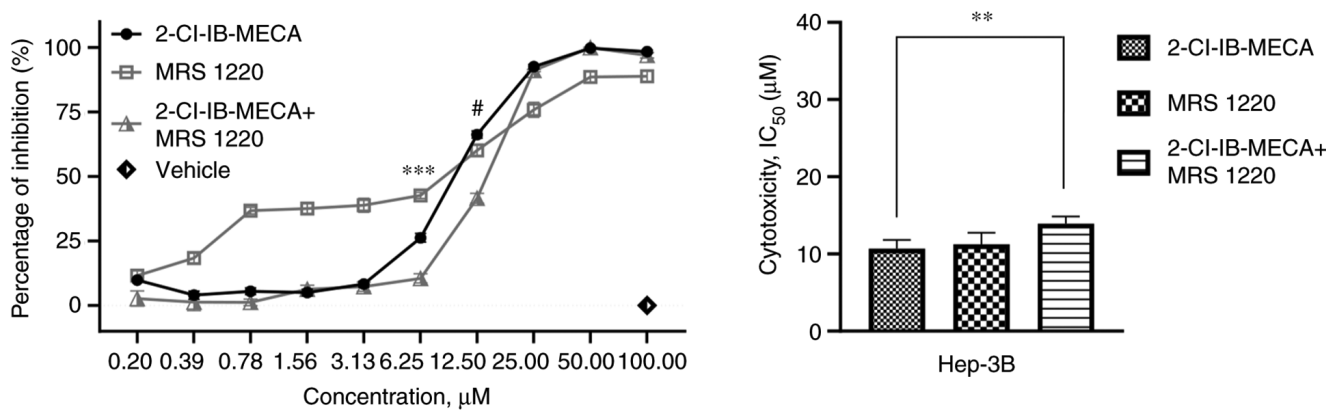

Figure 1. 2-Cl-IB-MECA demonstrates $\mathrm{A}_{3} \mathrm{AR}$ agonistic activity and cytotoxic effects on cancer cells. (A) Structure of 2-Cl-IB-MECA. (B) Functional assay was performed with the reporter cell line stably expressing $\mathrm{A}_{3} \mathrm{AR}$. The cells were treated with the indicated concentrations of 2-Cl-IB-MECA or MRS 1220, and the relative luminescence response for each independent experiment was normalized to the maximal response of a reference agonist $\mathrm{NECA} \mathrm{EC}_{50}$ and $\mathrm{IC}_{50}$ values were calculated. $n=4$. (C) Comparison of $A_{3} A R$ expression in the tested cell lines was analyzed using western blot. $A_{3} A R$ relative signal intensities were calculated using densitometry. n=3. Cytotoxicity of 2-Cl-IB-MECA and MRS 1220 alone, and in combination in the (D) JoPaca-1 and (E) Hep-3B cancer cell lines were analyzed using a MTS assay after $72 \mathrm{~h}$. The cells were treated at the indicated concentrations of 2-Cl-IB-MECA, MRS 1220 or 2-Cl-IB-MECA after 30-min pre-treatment with $0.1 \mu \mathrm{M}$ MRS 1220 . The values are expressed as the percentage of inhibition (left) and cytotoxicity IC $\mathrm{C}_{50}(\mathrm{right}) . \mathrm{n}=3$. The data are represented as the mean $\pm \mathrm{SD}$. The results were analyzed using a Student's two-tailed t-test. ${ }^{*} \mathrm{P}<0.05,{ }^{* *} \mathrm{P}<0.01,{ }^{* * *} \mathrm{P}<0.005,{ }^{\#} \mathrm{P}<0.001$ for 2 -Cl-IB-MECA vs. 2-Cl-IB-MECA + MRS 1220. 2-Cl-IB-MECA, 2-chloro-N6-(3-iodobenzyl)-5'-N-methylcarboxamidoadenosine; MRS 1220, N-[9-Chloro-2-(2-furanyl) $(1,2,4)$-triazolo(1,5-c)quinazolin-5-yl]benzene acetamide.

number of cells in the $\mathrm{S}$ phase was further accentuated by the drop in the cell population actively incorporating BrdU and BrU, indicating an inhibition of DNA (Fig. 2E), and RNA synthesis (Fig. 2F), respectively. Notably, pre-treatment with $0.1 \mu \mathrm{M}$ MRS 1220 significantly reversed the effects of 2-Cl-IB-MECA on BrdU (in the JoPaca-1 cell line at $20 \mathrm{nM}$ and $20 \mu \mathrm{M}$ of 2-Cl-IB-MECA) and $\mathrm{BrU}$ incorporation (in the Hep-3B cell line at $20 \mathrm{nM}$ and $20 \mu \mathrm{M}$ of 2-Cl-IB-MECA). 
Table I. Cytotoxicity of 2-Cl-IB-MECA in tumor and non-tumor cell lines.

\begin{tabular}{lcc}
\hline Cell line & $\mathrm{IC}_{50}, \mu \mathrm{M}$ & $\mathrm{SD}$ \\
\hline A549 & 45.51 & 5.73 \\
BT-549 & 12.48 & 0.67 \\
CCRF-CEM & 21.39 & 1.05 \\
CEM-DNR & 26.72 & 5.35 \\
HCT116 & 33.73 & 3.07 \\
HCT116 p53-- & 31.50 & 3.27 \\
Hep-3B & 10.68 & 1.14 \\
JoPaca-1 & 25.26 & 1.57 \\
K562 & 24.85 & 3.28 \\
K562-TAX & 29.23 & 2.78 \\
MDA-MB-231 & 23.89 & 4.14 \\
U2OS $^{\text {BJ }}$ & 42.78 & 7.69 \\
MRC-5 $^{\mathrm{a}}$ & $>50$ & - \\
\hline
\end{tabular}

${ }^{\text {a} N o n-t u m o r ~ c e l l ~ l i n e . ~ 2-C l-I B-M E C A, ~ 2-c h l o r o-N 6-(3-i o d o b e n z y l)-5 '-~}$ $\mathrm{N}$-methylcarboxamidoadenosine.

There was also decrease in RNA synthesis in the JoPaca-1 cell line following treatment with $0.1 \mu \mathrm{M}$ MRS 1220 , suggesting a possible intrinsic effect of MRS 1220 alone.

With respect to the JoPaca-1 cell line, the minor changes in the number of cells in the $\mathrm{G}_{2} / \mathrm{M}$ phase were mirrored by the decrease in the mitosis marker histone $\mathrm{H} 3$ phosphorylated at $\operatorname{Ser}^{10}$ (Fig. 2D).

2-Cl-IB-MECA regulates the proliferation signaling pathways. To further understand the mechanism of 2-Cl-IB-MECA in the pancreatic and HCC cell lines, the protein expression level of three essential pathways, previously indicated to be affected, either directly or indirectly, by AdoRs and their modulators (57), was analyzed. The JoPaca-1 and Hep-3B cell lines were treated with vehicle or $20 \mu \mathrm{M}$ 2-Cl-IB-MECA for 24 and $48 \mathrm{~h}$. The cells were pre-treated with $0.1 \mu \mathrm{M}$ MRS 1220 for $30 \mathrm{~min}$ prior to the addition of 2-Cl-IB-MECA, to confirm whether the effects were $\mathrm{A}_{3} \mathrm{AR}$ mediated.

First, $\mathrm{A}_{3} \mathrm{AR}$ protein expression level was analyzed after 24 and $48 \mathrm{~h}$ of 2-Cl-IB-MECA treatment. There was a decrease in $\mathrm{A}_{3} \mathrm{AR}$ protein expression level in the Hep-3B cell line, while there were no changes in the JoPaca-1 cell line (Fig. 3). Then, the expression level of proteins in the PI3K/AKT/NF- $\mathrm{KB}$ pathway were analyzed (53). It was found in both cell lines that the proliferation-related proteins, AKT and NF- $\mathrm{KB}$, were phosphorylated, at $\mathrm{Ser}^{473}$ and $\mathrm{Ser}^{536}$, respectively, in a time-dependent manner, after 2-Cl-IB-MECA treatment alone. Surprisingly, AKT kinase was dephosphorylated at $\mathrm{Thr}^{308}$ following 2-Cl-IB-MECA treatment for 24 and $48 \mathrm{~h}$ in the JoPaca-1 cell line, and after $48 \mathrm{~h}$ in the Hep-3B cell. line. Furthermore, the results demonstrated that MRS 1220 pre-treatment did not prevent 2-Cl-IB-MECA from most of its effects at 24 and $48 \mathrm{~h}$, with the exception of AKT at $\mathrm{Thr}^{308}$ and pNF- $\kappa \mathrm{B}$ at $\mathrm{Ser}^{536}$ (Fig. 3). Notably, there were differences between the JoPaca-1 and Hep-3B cell lines in the expression and phosphorylation of ERK1/2. The Hep-3B cell line showed a decrease in the expression level of ERK1/2 and pERK1/2 following treatment for $48 \mathrm{~h}$ with 2-Cl-IB-MECA and in combination with MRS 1220; however, total and phosphorylated ERK1/2 protein expression level in the JoPaca-1 cell line was increased in the same experimental groups in a time-dependent manner.

Another signaling pathway that has been associated with several types of cancer, including pancreatic and $\mathrm{HCC}$, is the Wnt/ $\beta$-catenin pathway $(58,59)$. Therefore, the effects of 2 -Cl-IB-MECA on the protein expression level of $\beta$-catenin and GSK-3 $\beta$ kinase, two main molecules in the Wnt signaling pathway were analyzed (Fig. 4). The $\beta$-catenin protein expression levels were decreased in both cell lines following 2-Cl-IB-MECA treatment for 24 and $48 \mathrm{~h}$. Surprisingly, GSK-3 $\beta$ kinase expression did not change distinctly in either cell line within the same experimental group as $\beta$-catenin. In addition, its phosphorylated form, pGSK-3 $\beta$, remained unaltered in the JoPaca-1 cell line, but was increased in the Hep-3B cell line after 2-Cl-IB-MECA treatment at $48 \mathrm{~h}$, suggesting that kinase inactivation only occurs in the Hep-3B cell line. Notably, these effects on the components of the Wnt/ $\beta$-catenin signaling pathway were partially abrogated by the $\mathrm{A}_{3} \mathrm{AR}$ antagonist, MRS 1220.

The Shh/Ptch/Gli axis was identified as another relevant pathway for bypassing cell death for malignant pancreatic and liver cells (59-61). The essential component of the Shh pathway, the Gli1 transcription factor, further regulates the expression level of cyclin D1, c-Myc, and Ptch1 receptor, another key molecule of the Shh pathway. In the JoPaca-1 and Hep-3B cell lines, 2-Cl-IB-MECA-mediated the decrease in the protein expression level of both Gli1 and Ptch1 in a time-dependent manner. Furthermore, the protein expression level of cyclin D1 and c-Myc, together with the c-Myc phosphorylated forms, was reduced following treatment with 2-Cl-IB-MECA alone for 24 and $48 \mathrm{~h}$. These effects were, however, partially reversed by MRS 1220 (Fig. 4).

Furthermore, $\beta$-catenin transcriptional activity upon 2-Cl-IB-MECA treatment was analyzed using a reporter system at various time points (Fig. 5). $\beta$-catenin can bind to the TCF/LEF transcription factor, triggering subsequent transcriptional activity of $\mathrm{Wnt} / \beta$-catenin pathway target genes, e.g. c-Myc and cyclin D1 $(62,63)$. Therefore, three reporter systems were designed to assess the transcriptional activity of: The WT Wnt $/ \beta$-catenin pathway $\left(\beta\right.$-catenin $\left.{ }^{\mathrm{WT}}\right)$; a $\beta$-catenin mutation that prevents its proteasomal degradation $\left(\beta\right.$-catenin $\left.{ }^{\text {mut }}\right)$; and a loss of function of the APC gene, which is critical for binding $\beta$-catenin in a complex with AXIN and, thus, regulates $\beta$-catenin availability for transcription ( $\left.\mathrm{APC}^{\mathrm{mu}}\right)$. The $\beta$-catenin ${ }^{\mathrm{WT}}$ (Fig. 5A), $\beta$-catenin ${ }^{\text {mut }}$ and $\mathrm{APC}^{\text {mut }}$ (Fig. 5B) reporter cell lines were treated with either vehicle, $50 \mu \mathrm{M}$ 2-Cl-IB-MECA or $0.1 \mu \mathrm{M}$ MRS 1220 for $30 \mathrm{~min}$ followed by $50 \mu \mathrm{M} 2$-Cl-IB-MECA. MTS assays were performed in parallel for 24 and $48 \mathrm{~h}$ to distinguish any decline in reporter activities from simple cytotoxic effects. The results indicated early inhibition of $\beta$-catenin transcription. WT transcriptional activity was inhibited by $75 \%$ after 6 h (Fig. 5A). Furthermore, 2-Cl-IB-MECA was more effective in the mutated reporter systems, where 2-Cl-IB-MECA completely abrogated 
A

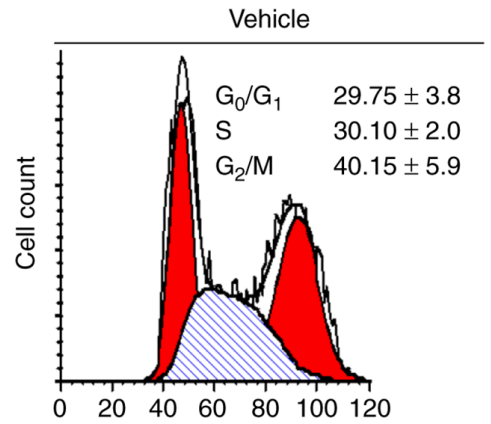

B

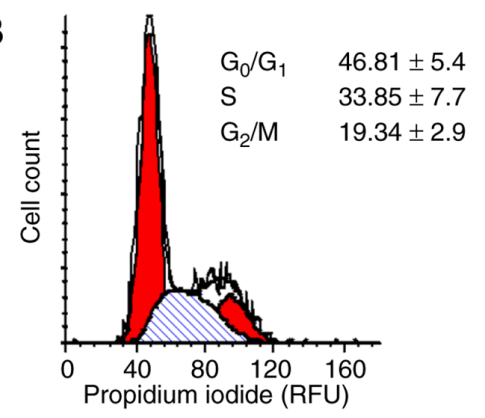

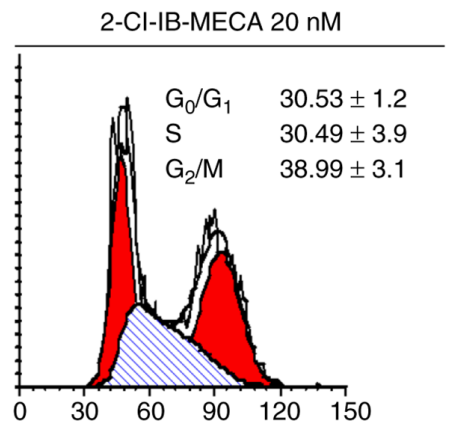
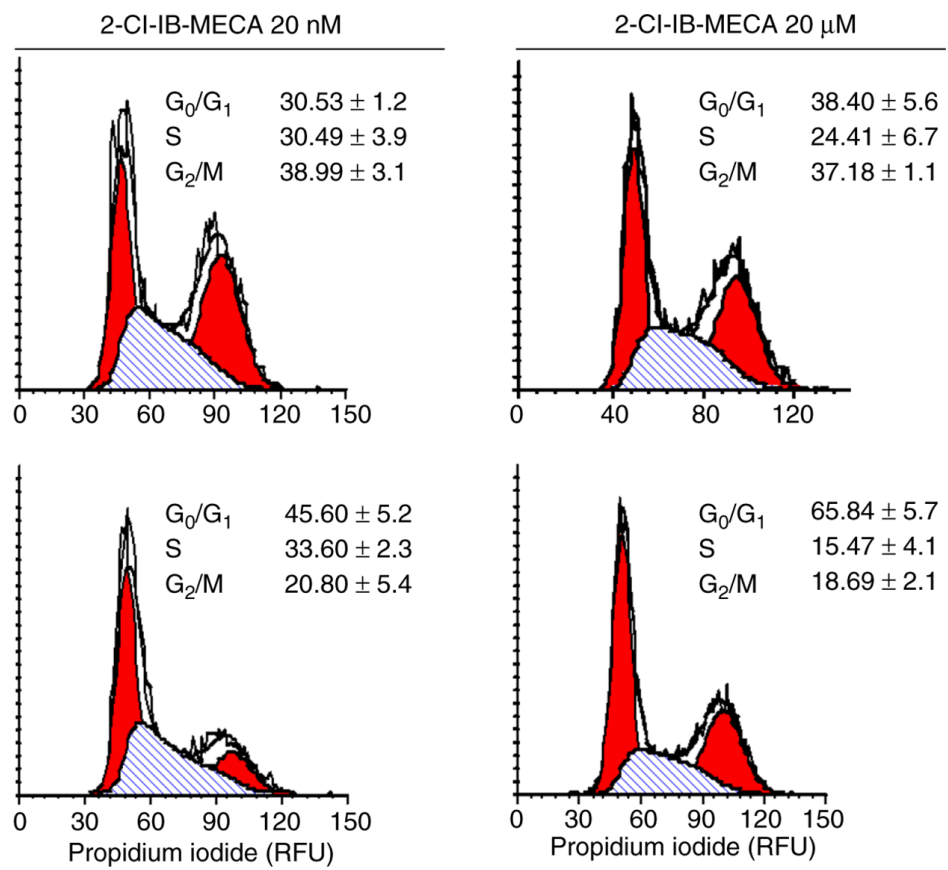

C

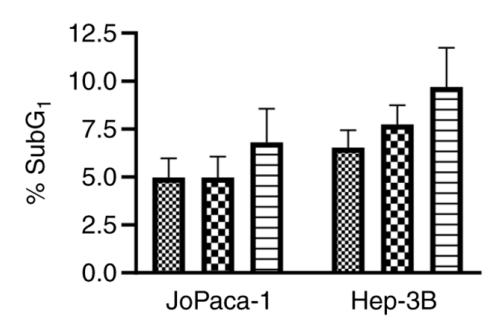

D

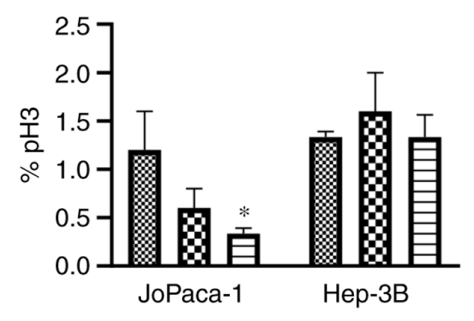

E
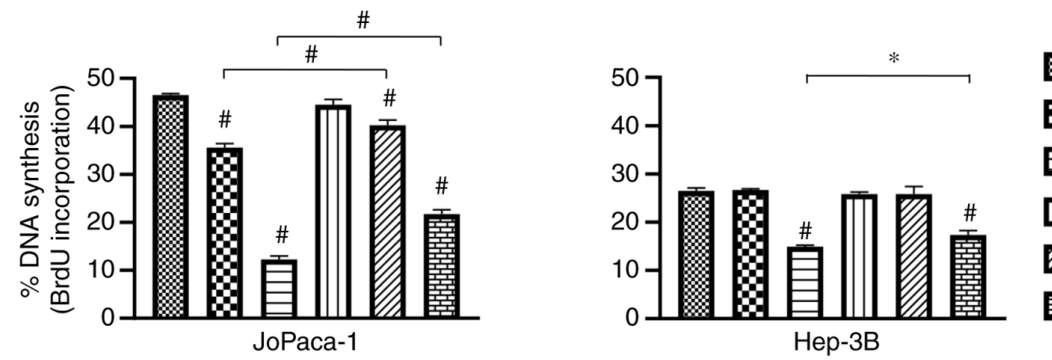

Vehicle

2-CI-IB-MECA $20 \mathrm{nM}$

曰 2-CI-IB-MECA $20 \mu \mathrm{M}$

MRS 1220

2-CI-IB-MECA $20 \mathrm{nM}+\mathrm{MRS}$

JoPaca-1

F
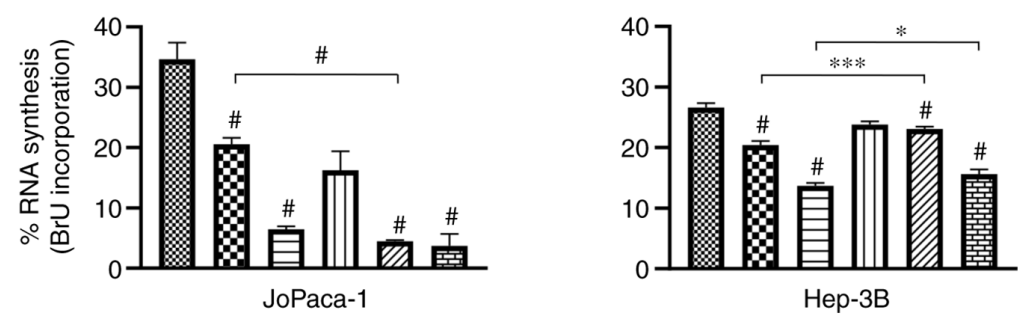

Hep-3B

Figure 2. 2-Cl-IB-MECA treatment leads to the alteration of cell cycle progression in the JoPaca-1 and Hep-3B cell lines. Cell cycle analysis of (A) JoPaca-1 and (B) Hep-3B cell lines following 2-Cl-IB-MECA treatment. The cells were treated with vehicle (DMSO) or the indicated concentrations of 2-Cl-IB-MECA $(20 \mathrm{nM}$ or $20 \mu \mathrm{M})$ for $24 \mathrm{~h}$. Cell cycle phase distribution $\left(\mathrm{G}_{0} / \mathrm{G}_{1}\right.$, 1st red peak; S, stripes; $\mathrm{G}_{2} / \mathrm{M}$. 2 nd red peak) was quantified as RFU. (C) quantification of subG $_{1}$ cells and (D) cell population positive for $\mathrm{pH} 3$ at $\mathrm{Ser}^{10}$ were analyzed separately. $\mathrm{n}=3$. All data are expressed as a percentage of the whole. $(\mathrm{E}) \mathrm{BrdU}$ and (F) BrU incorporation representing the percentage of the cells actively synthesizing DNA and RNA for JoPaca-1 (left) and Hep-3B (right) cell lines, treated with vehicle (DMSO), 2-Cl-IB-MECA (20 nM and $20 \mu \mathrm{M}$ ), or 30 min pre-treatment with $0.1 \mu \mathrm{M}$ MRS 1220 followed by 2-Cl-IB-MECA (20 nM and $20 \mu \mathrm{M})$, respectively. $\mathrm{n}=3$. Data was analyzed using one-way ANOVA with Tukey's post hoc multiple comparison test. All the data are represented as the mean \pm SD. ${ }^{*} \mathrm{P}<0.05,{ }^{* * * *} \mathrm{P}<0.005,{ }^{,} \mathrm{P}<0.001$ vs. vehicle, 2-Cl-IB-MECA vs. 2-Cl-IB-MECA + MRS 1220. RFU, relative fluorescence units; pH3, phosphorylated histone H3; BrdU, 5-Bromo-2'-deoxyuridine; BrU, 5-Bromouridine; 2-Cl-IB-MECA, 2-chloro-N6-(3-iodobenzyl)-5'-N-methylcarboxamidoadenosine; MRS 1220, N-[9Chloro-2-(2-furanyl)(1,2,4)-triazolo(1,5-c)quinazolin-5-yl]benzene acetamide.

$\beta$-catenin transcription within $12 \mathrm{~h}$ (Fig. 5B). This early decline in transcriptional activity was not primarily caused by inhibited proliferation and the degree of MRS 1220 antagonism against 2-Cl-IB-MECA was insignificant in this case. 
A

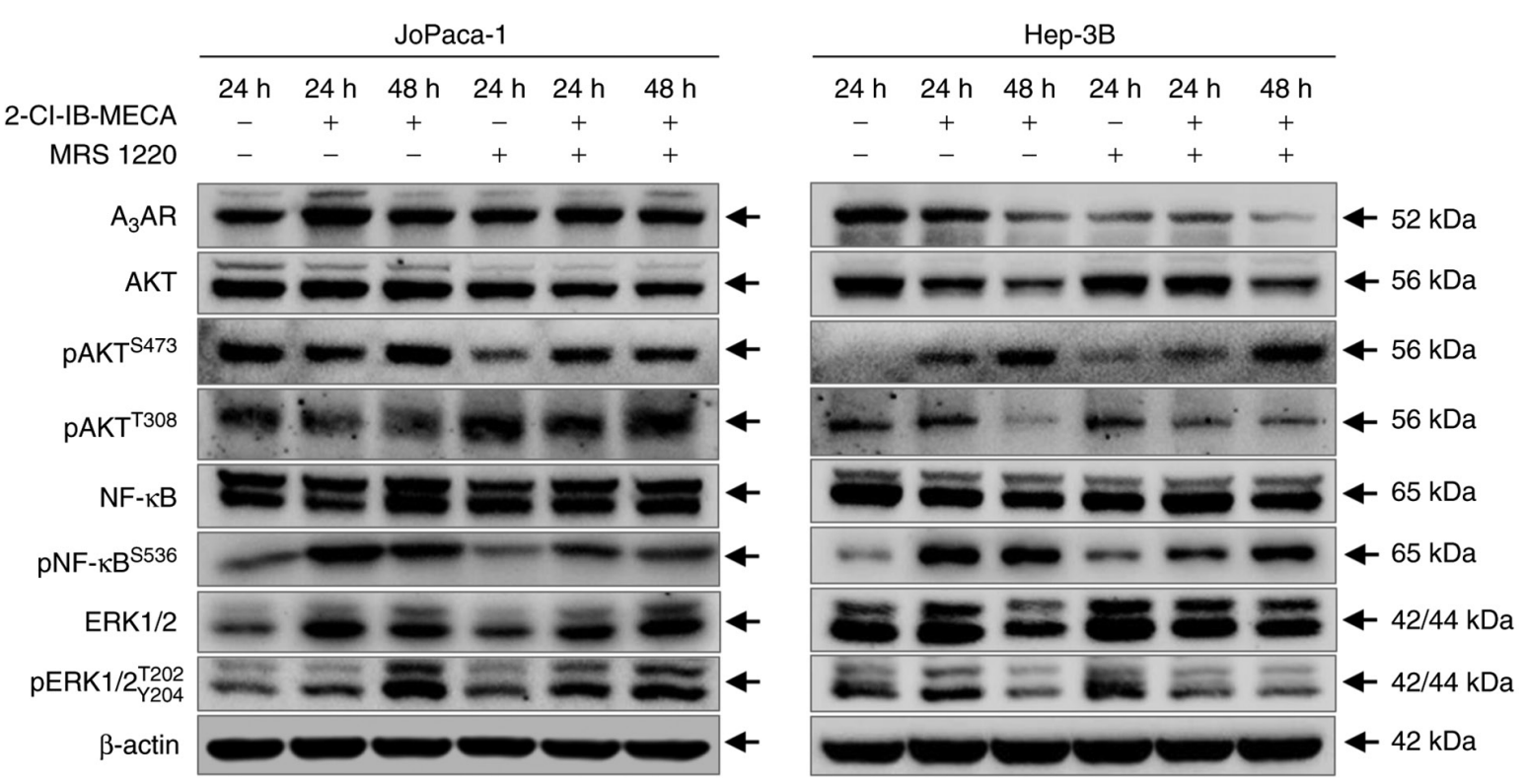

JoPaca-1

$\square$ Vehicle 目MRS 1220

— 2-CI-IB-MECA

口 2-CI-IB-MECA+MRS 1220

$\mathrm{B}$

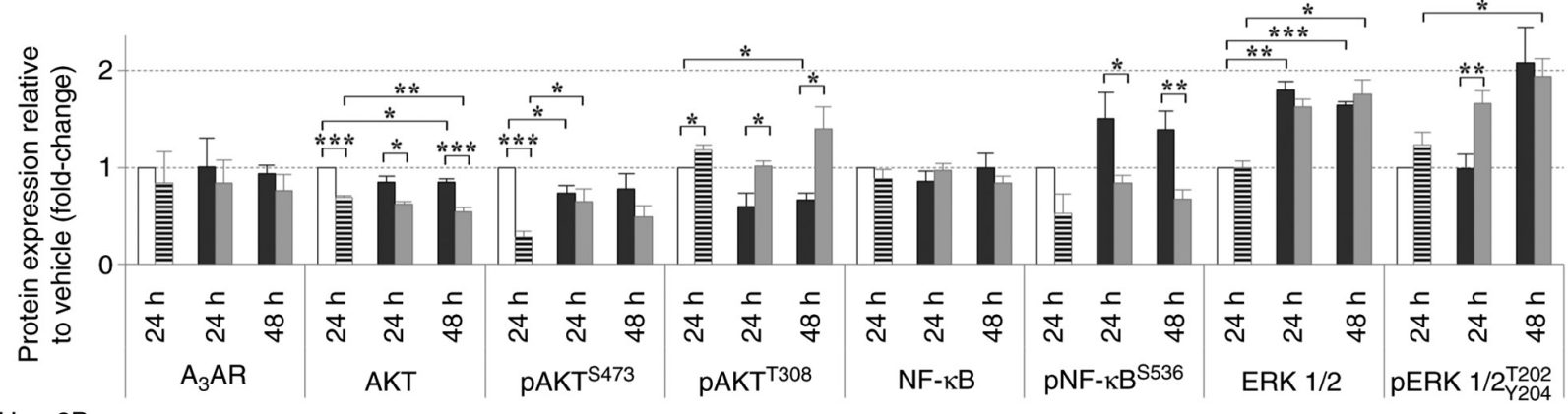

Hep-3B

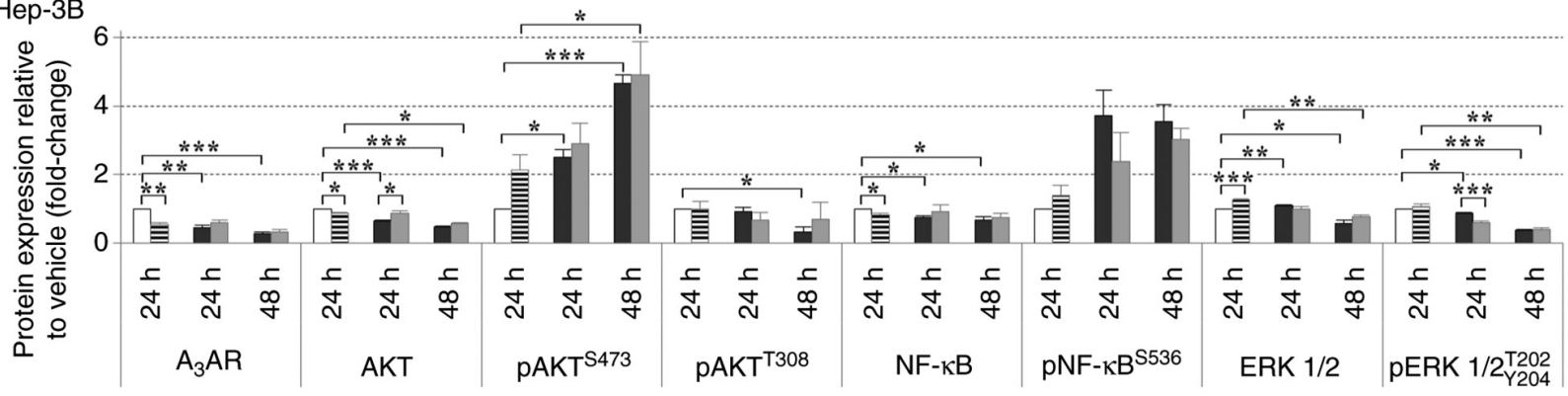

C

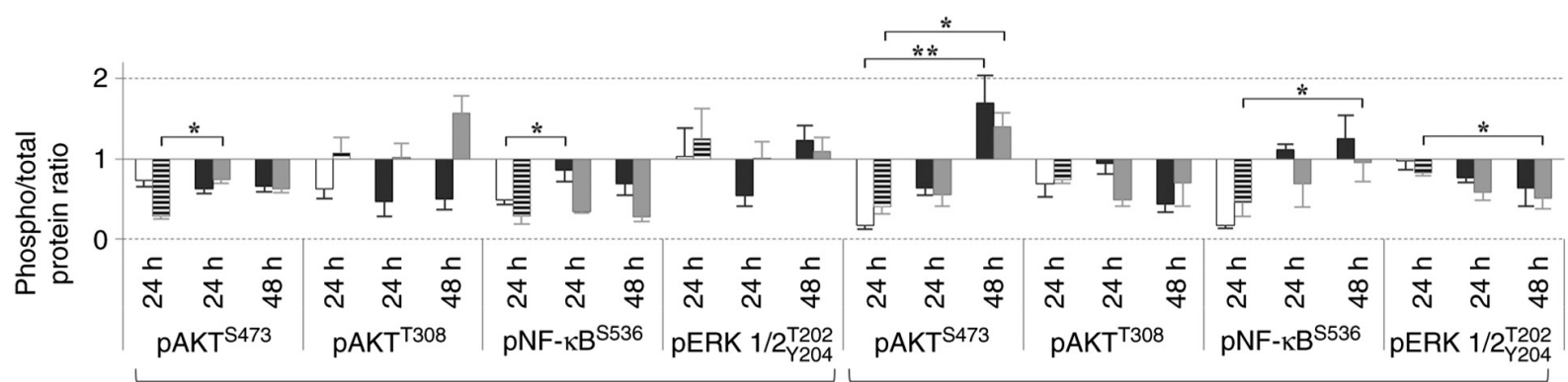

JoPaca-1

Hep-3B

Figure 3. 2-Cl-IB-MECA regulates key components of the PI3K/AKT/NF- $\mathrm{BB}$ proliferation signaling pathway in the JoPaca-1 and Hep-3B cell lines. (A) Western blot analysis of the PI3K/AKT/NF-KB pathway-related proteins in the JoPaca-1 (left) and Hep-3B (right) cells treated either with vehicle (DMSO), $0.1 \mu \mathrm{M}$ MRS 1220 for $24 \mathrm{~h}, 2-C l-I B-M E C A(20 \mu \mathrm{M})$ for 24 and $48 \mathrm{~h}$, or $30 \mathrm{~min}$ MRS $1220(0.1 \mu \mathrm{M})$ pre-treatment and 2-Cl-IB-MECA (20 $\mu \mathrm{M})$ for 24 and $48 \mathrm{~h}$. Representative blots from 3 replicates is shown. (B) Quantitative analysis of protein expression level. Protein relative intensities were calculated using densitometry analysis and expressed as fold change relative to vehicle. The data are presented as the mean \pm SD. $n=3$. The data were analyzed using Student's one-sample t-test (treatment vs. vehicle), two-sample t-test and one-way ANOVA with Dunn's test (2-Cl-IB-MECA vs. 2-Cl-IB-MECA + MRS 1220). (C) Ratio of phosphorylated vs. total protein for JoPaca-1 (left) and Hep-3B (right) cell lines. Statistical significance was analyzed with one-way ANOVA with Dunn's test. Symbols indicate vehicle vs. 2-Cl-IB-MECA and vehicle vs. 2 -Cl-IB-MECA + MRS $1220 .{ }^{*} \mathrm{P}<0.05,{ }^{* *} \mathrm{P}<0.01,{ }^{* * *} \mathrm{P}<0.005 . \mathrm{A}_{3} \mathrm{AR}, \mathrm{A}_{3}$ adenosine receptor; p, phosphorylated; 2-Cl-IB-MECA, 2-chloro-N6-(3-iodobenzyl)-5'-N-methylcarboxamidoadenosine; MRS 1220, N-[9-Chloro-2-(2-furanyl) $(1,2,4)$-triazolo(1,5-c)quinazolin-5-yl]benzene acetamide. 
A

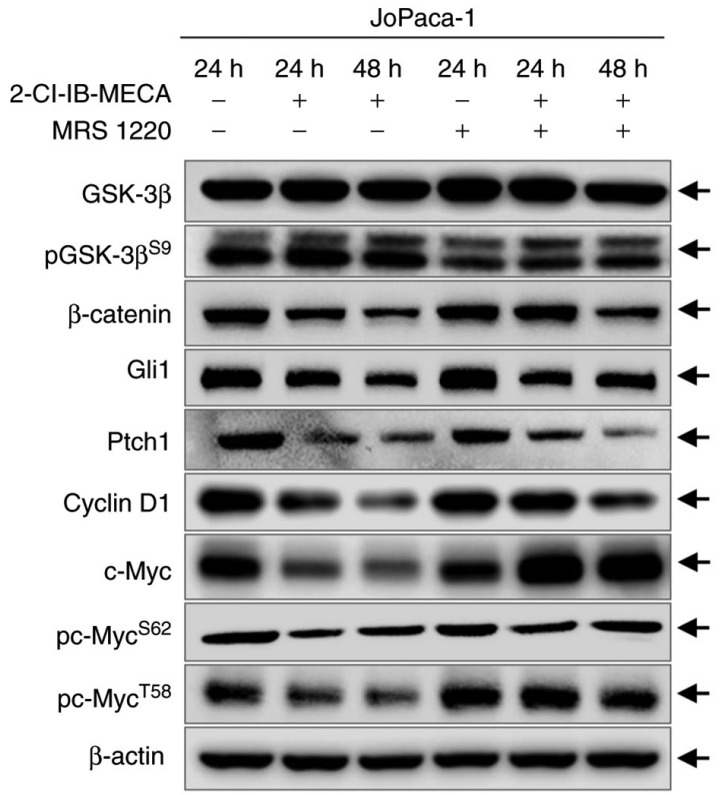

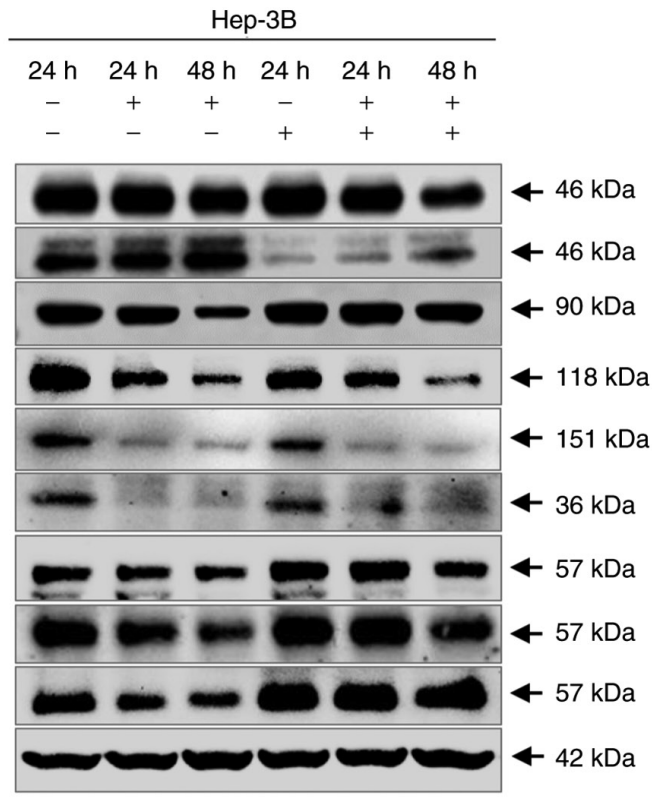

B

JoPaca-1

$\square$ Vehicle 目MRS $1220 \square$ 2-CI-IB-MECA $\square$ 2-CI-IB-MECA+MRS 1220
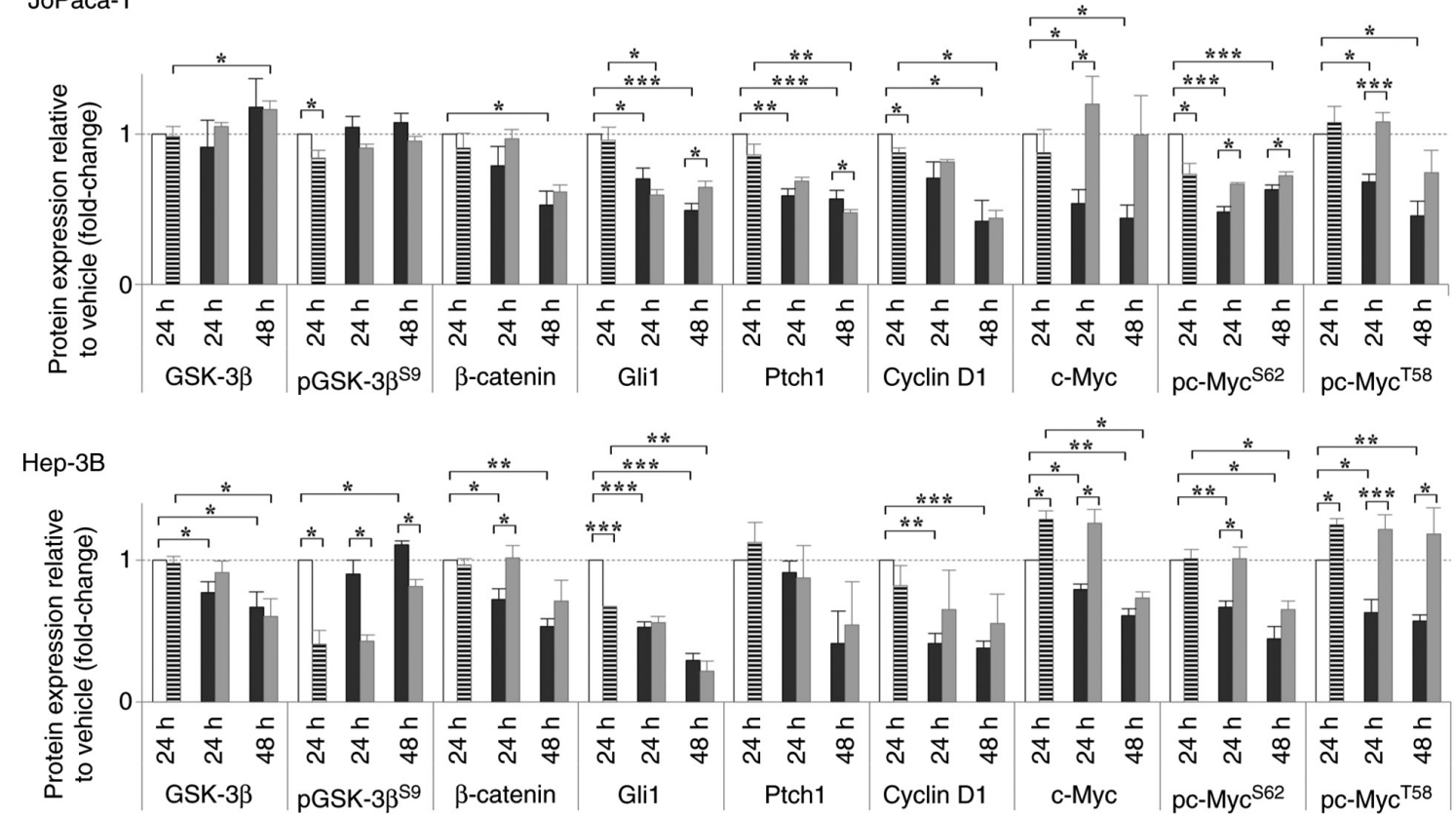

C

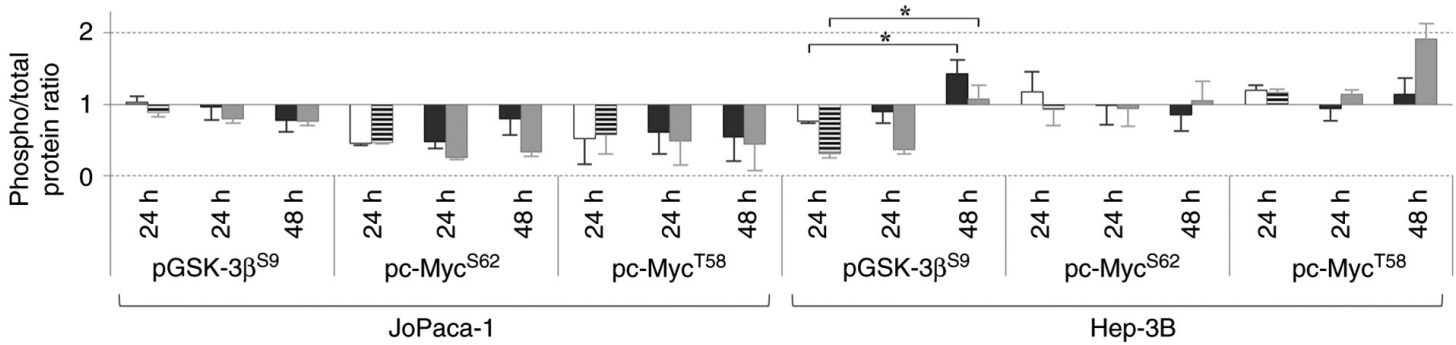

Figure 4. 2-Cl-IB-MECA regulates key components of the Wnt//-catenin and Shh/Ptch/Gli proliferation signaling pathways in the JoPaca-1 and Hep-3B cell lines. (A) Western blot analysis of the Wnt/ $\beta$-catenin and Shh/Ptch/Gli pathway-related proteins in the JoPaca-1 (left) and Hep-3B (right) cell lines treated either with vehicle (DMSO), $0.1 \mu \mathrm{M}$ MRS 1220 for $24 \mathrm{~h}, 2$-Cl-IB-MECA $(20 \mu \mathrm{M})$ for 24 and $48 \mathrm{~h}$, or 30 min of MRS $1220(0.1 \mu \mathrm{M})$ pre-treatment and 2-Cl-IB-MECA $(20 \mu \mathrm{M})$ for 24 and $48 \mathrm{~h}$. Representative image from 3 replicates is shown. (B) Quantitative analysis of protein expression level. Protein relative intensities were calculated using densitometry and expressed as fold change relative to vehicle. The data are presented as the mean \pm SD. $n=3$. The data was analyzed using Student's one-sample t-test (treatment vs. vehicle), two-sample t-test and one-way ANOVA with Dunn's test (2-Cl-IB-MECA vs. 2-Cl-IB-MECA + MRS 1220). (C) Ratio of phosphorylated vs. total protein for the JoPaca-1 (left) and Hep-3B (right) cell lines. Statistical significance was analyzed with one-way ANOVA with Dunn's test. Symbols indicate vehicle vs. 2-Cl-IB-MECA and vehicle vs. 2-Cl-IB-MECA + MRS 1220. ${ }^{*} \mathrm{P}<0.05$, ${ }^{* *} \mathrm{P}<0.01$,

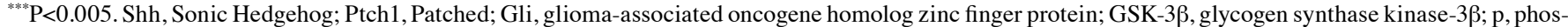
phorylated; 2-Cl-IB-MECA, 2-chloro-N6-(3-iodobenzyl)-5'-N-methylcarboxamidoadenosine; MRS 1220, N-[9-Chloro-2-(2-furanyl)(1,2,4)-triazolo(1,5-c) quinazolin-5-yl]benzene acetamide. 
A

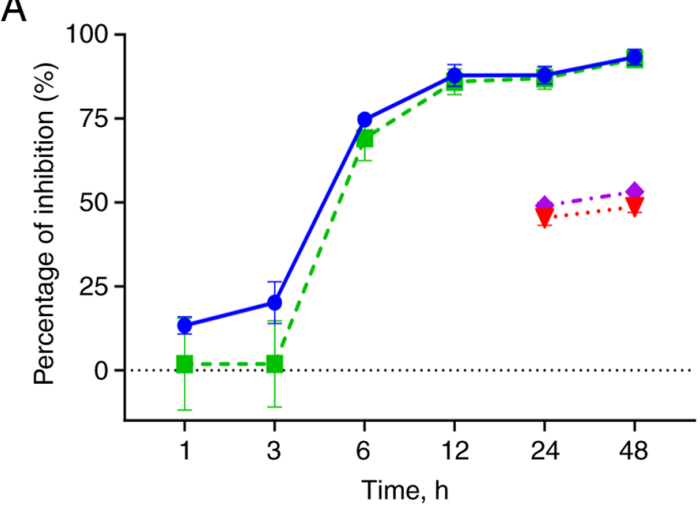

$-\beta$-catenin ${ }^{\mathrm{WT}}$
$-\beta$-catenin ${ }^{\mathrm{WT}}+\mathrm{MRS}$
- $\beta$-catenin ${ }^{\mathrm{WT}} \mathrm{MTS}$
$-\beta$-catenin ${ }^{\mathrm{WT}}+\mathrm{MRS}$ MTS
B

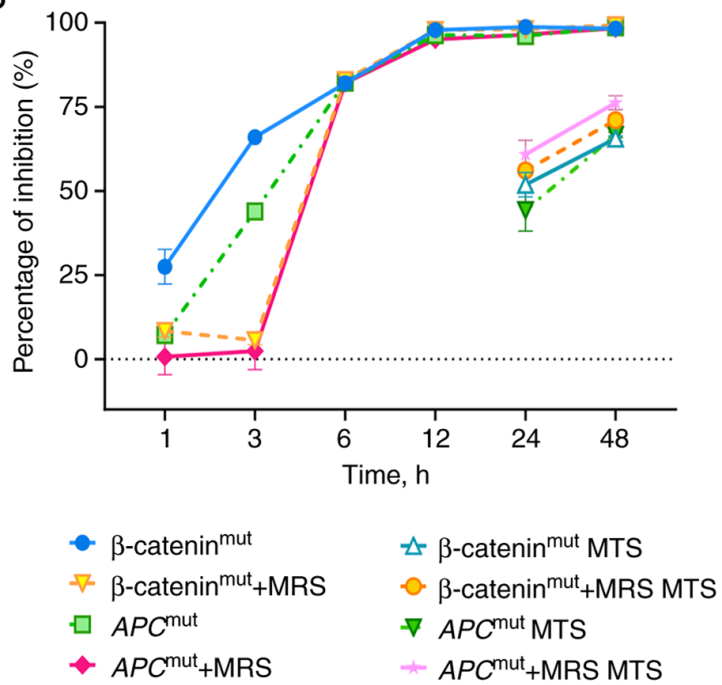

Figure 5. 2-Cl-IB-MECA downregulates $\beta$-catenin transcriptional activity in WT and mutated Wnt $/ \beta$-catenin reporters. (A) Reporter assay of $\beta$-catenin transcriptional activity in $\beta$-catenin ${ }^{\mathrm{WT}}$ and $(\mathrm{B})$ mutated $\left(\beta\right.$-catenin ${ }^{\text {mut }}$ and $\left.\mathrm{APC}^{\mathrm{mut}}\right)$ reporter system after treatment with vehicle $(\mathrm{DMSO}), 2-\mathrm{Cl}-\mathrm{IB}-\mathrm{MECA}(50 \mu \mathrm{M})$, or $30 \mathrm{~min}$ MRS $1220(0.1 \mu \mathrm{M})$ pre-treatment and 2-Cl-IB-MECA $(50 \mu \mathrm{M})$ over time. For cytotoxicity comparisons of reporter activities, percentage of inhibition from a MTS assay, run in parallel, are included. Normalized data are shown as mean \pm SD. n=3. 2-Cl-IB-MECA, 2-chloro-N6-(3-iodobenzyl)-5'-Nmethylcarboxamidoadenosine; MRS 1220, N-[9-Chloro-2-(2-furanyl)(1,2,4)-triazolo(1,5-c)quinazolin-5-yl]benzene acetamide; WT, wild-type; mut, mutated.

2-Cl-IB-MECA reduces xenobiotic transporter $M R P 1$ and $P$-gp protein expression and $P$-gp function. Multidrug resistance (MDR) can seriously hinder anticancer treatment. Recently, some studies have reported an association between AdoRs and MDR (37,43). Therefore, MRP1 and P-gp protein expression level was analyzed in both the pancreatic and HCC cell lines. In addition to analyzing the protein expression levels, P-gp activity was also analyzed using a functional test of K562-TAX overexpressing P-gp protein.

To analyze the protein expression level, the cells were treated with either vehicle or $20 \mu \mathrm{M}$ 2-Cl-IB-MECA for $24 \mathrm{~h}$. The results indicated the reduction of MRP1 protein expression level after treatment with 2-Cl-IB-MECA, with a more significant effect in the Hep-3B cell line (Fig. 6A and B). P-gp expression was analyzed using flow cytometry under the same conditions. Similarly, P-gp overall expression was significantly attenuated by $20 \mu \mathrm{M} 2$-Cl-IB-MECA after $24 \mathrm{~h}$ (Fig. 6C and D). Of note, the Hep-3B cell line had higher endogenous P-gp levels.

Reducing P-gp expression could be a powerful tool against chemoresistance in cancer cells. Nonetheless, it was also investigated whether 2-Cl-IB-MECA could diminish the P-gp efflux function to any extent. Chemotherapeutic agent daunorubicin serves as the P-gp substrate and its intracellular uptake reflects P-gp ability to actively transport this xenobiotic from the cells (64). Therefore, P-gp functional ability to actively effuse daunorubicin when treated with 2-Cl-IB-MECA was analyzed. For this purpose, the K562-TAX cell line, with high P-gp expression, was used (45). The K562-TAX cells were incubated with $1 \mu \mathrm{M}$ daunorubicin for $1 \mathrm{~h}$ prior to treatment with either vehicle or 2-Cl-IB-MECA $(0.78-100 \mu \mathrm{M})$ for an additional $1 \mathrm{~h}$. For pre-treatment with MRS 1220, $0.1 \mu \mathrm{M}$ MRS 1220 was added $30 \mathrm{~min}$ before the $1 \mathrm{~h}$ incubation with 2-Cl-IB-MECA. Within $1 \mathrm{~h}$ of treatment, 2-Cl-IB-MECA, at high micromolar concentrations was able to increase P-gp efflux activity (Fig. 6E). This functional interference suggests that 2-Cl-IB-MECA is a direct substrate of P-gp. Surprisingly, the negative effects of 2-Cl-IB-MECA on P-gp function were partially abolished by $\mathrm{A}_{3} \mathrm{AR}$ antagonist MRS 1220 .

2-Cl-IB-MECA enhances anticancer effects of clinically relevant drugs. The aforementioned results showed that 2-Cl-IB-MECA mediated the inhibition of key components of the Wnt/ $\beta$-catenin and $\mathrm{Shh} / \mathrm{Ptch} /$ Gli pathways, together with disruption of the xenobiotic efflux system. These are two interlinked mechanisms in which cancer cells can resist pharmacotherapy $(60,61,65)$. Therefore, we hypothesized the beneficial effects of 2-Cl-IB-MECA could be part of a combined cancer treatment. First, cellular proliferation after treatment was normalized to vehicle as FA, then the derived analysis of the combination effect of two compounds was calculated. The resulting CI values for respective concentration ratios are shown in Fig. 7. The outcomes of treatment combinations were analyzed: 2-Cl-IB-MECA (1.56-50 $\mu \mathrm{M}$ for the JoPaca-1 cell line and $0.78-25 \mu \mathrm{M}$ for the Hep-3B cell line) and each of the following four current conventional chemotherapeutic agents: 5-FU $(0.78-200 \mu \mathrm{M})$, carboplatin $(0.78-200 \mu \mathrm{M})$, doxorubicin $(0.1-25 \mu \mathrm{M})$ and gemcitabine $(0.2-50 \mu \mathrm{M})$.

The JoPaca-1 and Hep-3B cell lines were treated with each compound alone and in either a concurrent or sequential combination comprising 2-Cl-IB-MECA and one of the four chemotherapeutics for $72 \mathrm{~h}$. For sequential combinations, 2-Cl-IB-MECA was added to the cells first, followed $16 \mathrm{~h}$ later by one of the chemotherapeutics, or vice versa. Possible synergistic or additive effects of 2-Cl-IB-MECA on cancer cell sensitivity to the aforementioned drugs were analyzed using a MTS assay. Endpoint analysis of cytotoxicity was performed $72 \mathrm{~h}$ after concurrent or sequential treatment and the CI was calculated. The degree of synergism, additive effect or antagonism was evaluated based on the CI method (48) and color coded (green indicates the highest synergy, while pink indicates no synergy). 
A

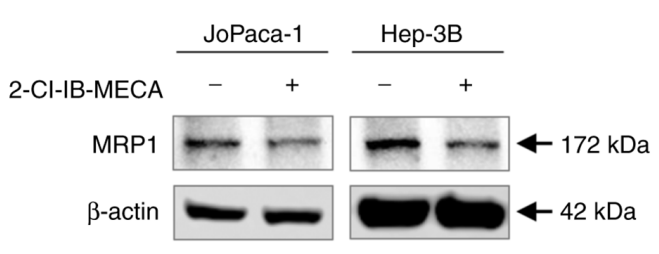

C

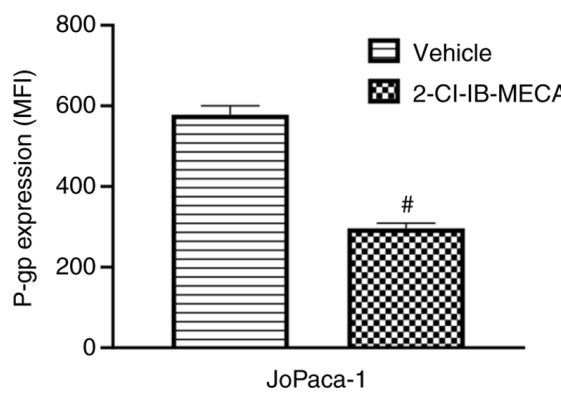

$\mathrm{D}$

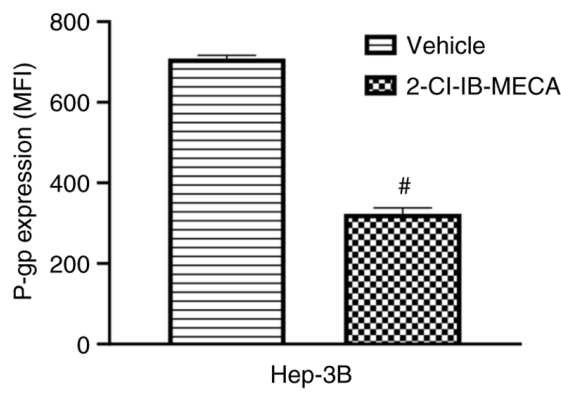

B
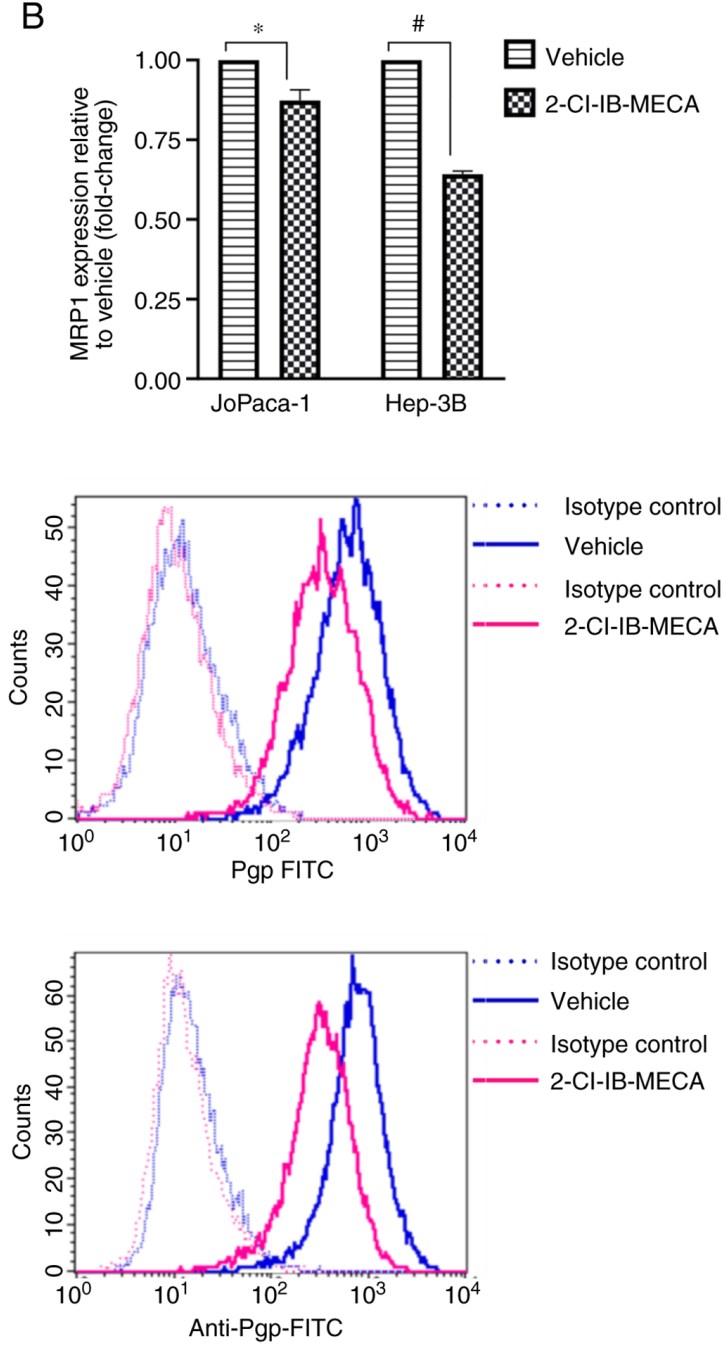

$\mathrm{E}$

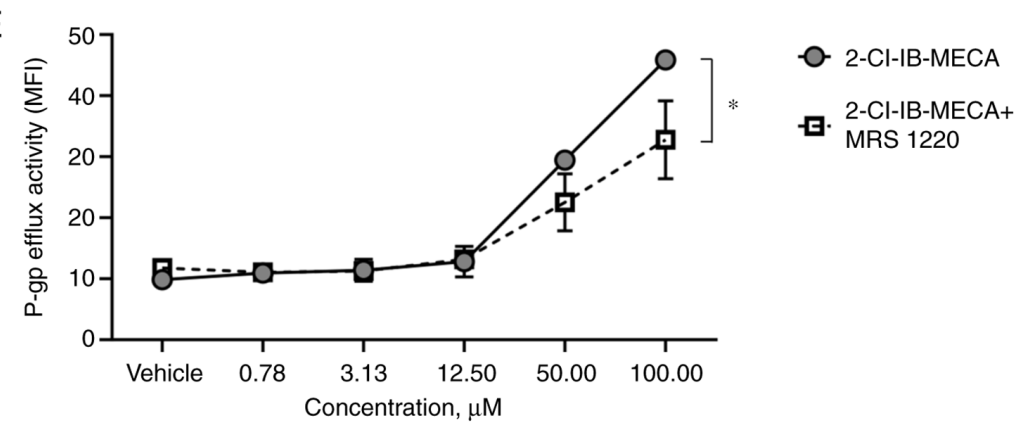

Figure 6. 2-Cl-IB-MECA deregulates multidrug resistance proteins, MRP1 and P-gp protein expression level and P-gp function. (A) Western blot analysis of MRP1 protein expression levels in the JoPaca-1 and Hep-3B cells treated either with vehicle (DMSO) or 2-Cl-IB-MECA (20 $\mu \mathrm{M}$ ) for $24 \mathrm{~h}$. (B) Densitometry analysis from western blot analysis. $\mathrm{n}=3$. The data was analyzed using a Student's one-sample t-test, and one representative image is shown. ${ }^{*} \mathrm{P}<0.05,{ }^{,} \mathrm{P}<0.001$ vs. vehicle. Flow cytometry analysis of P-gp total protein expression after vehicle (DMSO) or 2-Cl-IB-MECA (20 $\mu \mathrm{M})$ treatment for $24 \mathrm{~h}$ in the (C) JoPaca-1 and (D) Hep-3B cells. The data was analyzed using a Student's two-sample t-test, and one representative histogram with overlays of isotype controls and treatment is shown. ${ }^{~} \mathrm{P}<0.001$ vs. vehicle. (E) Quantification of P-gp efflux function after treatment with vehicle, different concentrations of 2-Cl-IB-MECA for $1 \mathrm{~h}$ or $0.1 \mu \mathrm{M}$ MRS 1220 for 30 min followed by 2-Cl-IB-MECA at different concentrations for $1 \mathrm{~h}$ in the K562-TAX cell lines overexpressing P-gp. Fluorescence intensity of daunorubicin detained or released from cells was measured and data were quantified as mean \pm SD. $n=3$. The data were analyzed using Student's two-sample t-test. "P<0.05. MFI, median fluorescence intensity; MRP1, multidrug resistance-associated protein 1; P-gp, P-glycoprotein; 2-Cl-IB-MECA, 2-chlo ro-N6-(3-iodobenzyl)-5'-N-methylcarboxamidoadenosine; MRS 1220, N-[9-Chloro-2-(2-furanyl)(1,2,4)-triazolo(1,5-c)quinazolin-5-yl]benzene acetamide.

In the JoPaca-1 cell line, synergistic effects for 2-Cl-IB-MECA concurrent combinations with carboplatin, doxorubicin and 5-FU were found at several concentration ratios (green color). For gemcitabine, synergy was found only if cells were concurrently treated with 2-Cl-IB-MECA at concentrations $\geq \mathrm{IC}_{50}$ (Fig. 7A). The Hep-3B cell line was more sensitive to 2-Cl-IB-MECA alone; therefore, the highest concentration of 2-Cl-IB-MECA was $25 \mu \mathrm{M}$ (Fig. 7B). Similar to the JoPaca-1 cell line, synergy was found in the Hep-3B cell line treated with multiple, independent, concomitant combinations of 2-Cl-IB-MECA with either carboplatin or doxorubicin, whereas 5-FU and gemcitabine showed synergistic effects 
A

\begin{tabular}{lll}
\hline DRUG & $\mathrm{IC}_{50}(\mu \mathrm{M})$ & $\mathrm{SD}$ \\
\hline 5-FU & 1.82 & 0.54 \\
Carboplatin & 225.30 & 18.22 \\
Doxorubicin & 0.54 & 0.04 \\
Gemcitabine & 2.96 & 0.17 \\
\hline
\end{tabular}

\begin{tabular}{ll|l|l|l|l|l|l|l|l|l|}
1.56 & 0.50 & 0.52 & 0.44 & 0.45 & 0.52 & 0.88 & 2.03 & 2.54 & 2.70 \\
\hline
\end{tabular}

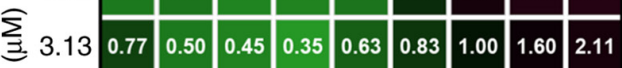

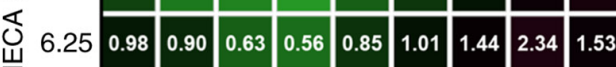

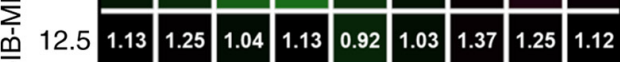

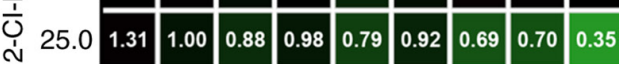

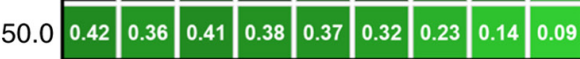

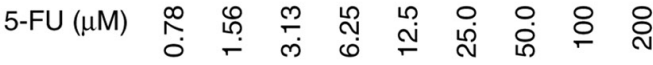

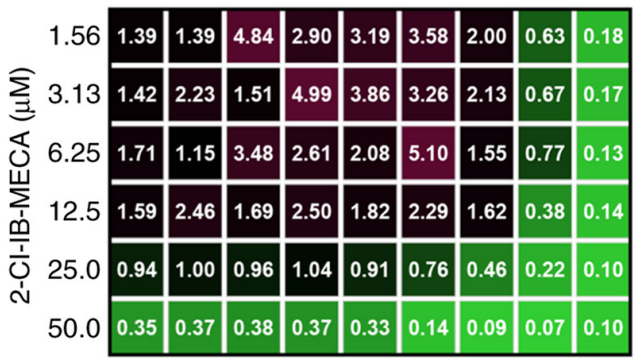

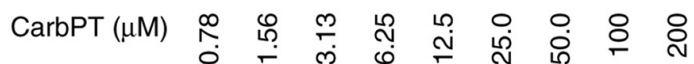
\begin{tabular}{ll|l|l|l|l|l|l|l|l|}
1.56 & 0.29 & 0.38 & 0.33 & 0.43 & 0.37 & 0.51 & 1.40 & 1.98 & 1.97 \\
\hline
\end{tabular}

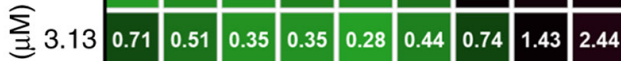

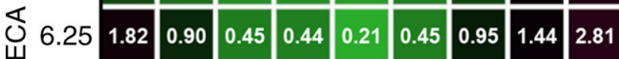

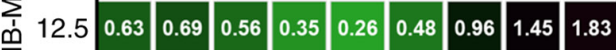

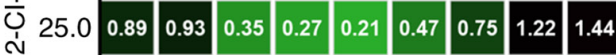

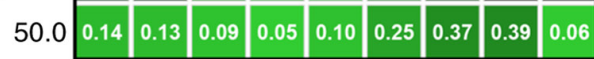

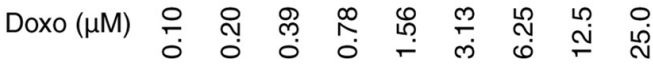

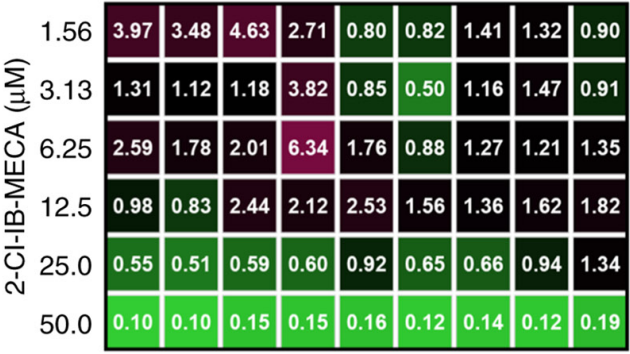

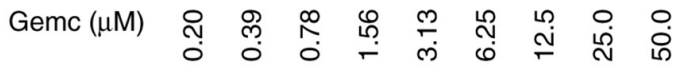

B

\begin{tabular}{lll}
\hline DRUG & $\mathrm{IC}_{50}(\mu \mathrm{M})$ & $\mathrm{SD}$ \\
\hline 5-FU & 0.74 & 0.36 \\
Carboplatin & 80.33 & 3.83 \\
Doxorubicin & 0.14 & 0.01 \\
Gemcitabine & 1.25 & 0.42 \\
\hline
\end{tabular}

\begin{tabular}{ll|l|l|l|l|l|l|l|l|l|}
0.78 & 1.83 & 0.83 & 0.51 & 0.33 & 0.27 & 0.39 & 0.74 & 2.73 & 4.44 \\
\hline
\end{tabular} \begin{tabular}{ll|l|l|l|l|l|l|l|l|}
1.56 & 2.10 & 1.14 & 0.68 & 0.45 & 0.41 & 0.87 & 1.34 & 5.16 & 9.00 \\
\hline
\end{tabular} \begin{tabular}{ll|l|l|l|l|l|l|l|l}
3.13 & 3.11 & 1.49 & 1.18 & 0.73 & 0.73 & 0.71 & 1.64 & 3.61 & 6.06 \\
\hline
\end{tabular} \begin{tabular}{llllll|l|l|l|l|l|l}
6.25 & 2.59 & 2.37 & 1.54 & 1.30 & 1.20 & 1.42 & 2.22 & 2.97 & 7.47 \\
\hline
\end{tabular} \begin{tabular}{ll|l|l|l|l|l|l|l|l|}
12.5 & 1.05 & 1.12 & 1.05 & 1.05 & 1.09 & 1.18 & 1.33 & 1.40 & 1.66 \\
\hline
\end{tabular} \begin{tabular}{ll|l|l|l|l|l|l|l|l}
25.0 & 0.44 & 0.46 & 0.33 & 0.41 & 0.48 & 0.47 & 0.59 & 0.31 & 0.31 \\
\hline
\end{tabular}

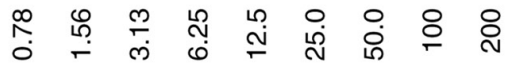

\begin{tabular}{|l|l|l|l|l|l|l|l|l|l|}
0.78 & 4.26 & 5.69 & 3.83 & 8.10 & 6.35 & 5.66 & 2.82 & 1.10 & 0.09 \\
\hline
\end{tabular} \begin{tabular}{ll|l|l|l|l|l|l|l|l}
1.56 & 9.09 & 4.60 & 5.50 & 4.51 & 4.38 & 3.76 & 2.83 & 0.87 & 0.25 \\
\hline
\end{tabular} \begin{tabular}{ll|l|l|l|l|l|l|l|l|}
\hline 3.13 & 4.91 & 6.39 & 8.35 & 11.07 & 7.14 & 4.47 & 2.76 & 1.12 & 0.17 \\
\hline
\end{tabular} \begin{tabular}{ll|l|l|l|l|l|l|l|l|}
6.25 & 4.25 & 4.47 & 5.83 & 5.11 & 5.06 & 4.48 & 2.58 & 1.18 & 0.15 \\
\hline
\end{tabular} \begin{tabular}{ll|l|l|l|l|l|l|l|l}
12.5 & 1.37 & 1.61 & 1.60 & 1.84 & 1.83 & 1.92 & 1.77 & 0.45 & 0.08 \\
\hline
\end{tabular} \begin{tabular}{ll|l|l|l|l|l|l|l|l|}
25.0 & 0.33 & 0.30 & 0.24 & 0.27 & 0.26 & 0.25 & 0.14 & 0.04 & 0.03 \\
\hline
\end{tabular} 市 \begin{tabular}{ll|l|l|l|l|l|l|l|l|}
0.78 & 1.44 & 0.66 & 0.37 & 0.25 & 0.65 & 1.10 & 1.75 & 2.34 & 1.51 \\
\hline
\end{tabular} \begin{tabular}{ll|l|l|l|l|l|l|l|l}
1.56 & 2.51 & 0.93 & 0.55 & 0.36 & 0.34 & 1.15 & 1.51 & 2.15 & 2.27 \\
\hline
\end{tabular} \begin{tabular}{ll|l|l|l|l|l|l|l|l}
\hline .13 & 2.54 & 1.13 & 0.60 & 0.39 & 0.38 & 0.72 & 1.38 & 2.00 & 1.34 \\
\hline
\end{tabular} \begin{tabular}{ll|l|l|l|l|l|l|l|l}
6.25 & 1.62 & 0.95 & 0.42 & 0.27 & 0.31 & 0.53 & 0.78 & 1.27 & 1.15 \\
\hline
\end{tabular} \begin{tabular}{l|l|l|l|l|l|l|l|l|l}
12.5 & 1.01 & 0.50 & 0.29 & 0.20 & 0.41 & 0.75 & 1.01 & 1.15 & 0.66 \\
\hline
\end{tabular}

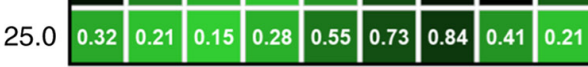
웅 तั

\begin{tabular}{lll|l|l|l|l|l|l|l|l|}
0.78 & 2.57 & 2.33 & 0.83 & 0.36 & 0.84 & 1.17 & 2.06 & 2.63 & 3.03 \\
\hline
\end{tabular} \begin{tabular}{ll|l|l|l|l|l|l|l|l}
1.56 & 4.90 & 3.12 & 1.29 & 0.56 & 0.80 & 1.43 & 2.14 & 2.92 & 3.41 \\
\hline
\end{tabular} \begin{tabular}{ll|l|l|l|l|l|l|l|l|}
3.13 & 4.36 & 6.18 & 2.35 & 0.90 & 1.11 & 1.35 & 2.29 & 3.03 & 3.20 \\
\hline
\end{tabular} \begin{tabular}{lllllllllllll}
6.25 & 3.60 & 5.17 & 4.24 & 1.59 & 1.65 & 1.91 & 2.02 & 2.88 & 2.94 \\
\hline
\end{tabular} \begin{tabular}{ll|l|l|l|l|l|l|l|l}
12.5 & 1.54 & 1.62 & 1.70 & 1.58 & 1.50 & 1.53 & 1.75 & 1.64 & 1.95 \\
\hline
\end{tabular} \begin{tabular}{ll|l|l|l|l|l|l|l|l}
25.0 & 0.41 & 0.54 & 0.29 & 0.50 & 0.37 & 0.44 & 0.36 & 0.39 & 0.35 \\
\hline
\end{tabular} 空

\begin{tabular}{lllll}
\hline 0.1 & 1 & 3 & 6 & 12
\end{tabular}

Figure 7. 2-Cl-IB-MECA mediates the enhancement of cytotoxicity of conventional chemotherapeutic agents in the JoPaca-1 and Hep-3B cell lines. (A) JoPaca-1 and (B) Hep-3B cells were treated with each of the following chemotherapeutic agents alone and in concurrent combination with 2-Cl-IB-MECA (1.56-50 $\mu \mathrm{M}$ for the JoPaca-1 cell line; 0.78-25 $\mu \mathrm{M}$ for the Hep-3B cell line) for $72 \mathrm{~h}: 5$-FU $(0.78-200 \mu \mathrm{M})$, CarbPT $(0.78-200 \mu \mathrm{M})$, Doxo $(0.1-25 \mu \mathrm{M})$ and Gemc $(0.2-50 \mu \mathrm{M})$. Cytotoxicity was analyzed using a MTS assay, followed by $\mathrm{IC}_{50}$ and $\mathrm{CI}$ calculations based on the Chou-Talalay method and using the CalcuSyn software. The cytotoxic $\mathrm{IC}_{50}$ results for each compound alone are expressed as the mean $\pm \mathrm{SD}$. $(\mathrm{n}=3)$. The results for combination treatments are represented as mean $\mathrm{CI}$ $(\mathrm{n}=3)$ and are color coded (green indicates high synergy and pink indicates no synergy). 5-FU, fluorouracil; CarbPT, carboplatin; Doxo, doxorubicin; Gemc, gemcitabine; CI, combination index; 2-Cl-IB-MECA, 2-chloro-N6-(3-iodobenzyl)-5'-N-methylcarboxamidoadenosine; MRS 1220, N-[9-Chloro-2-(2-furanyl) $(1,2,4)$-triazolo(1,5-c)quinazolin-5-yl]benzene acetamide. 


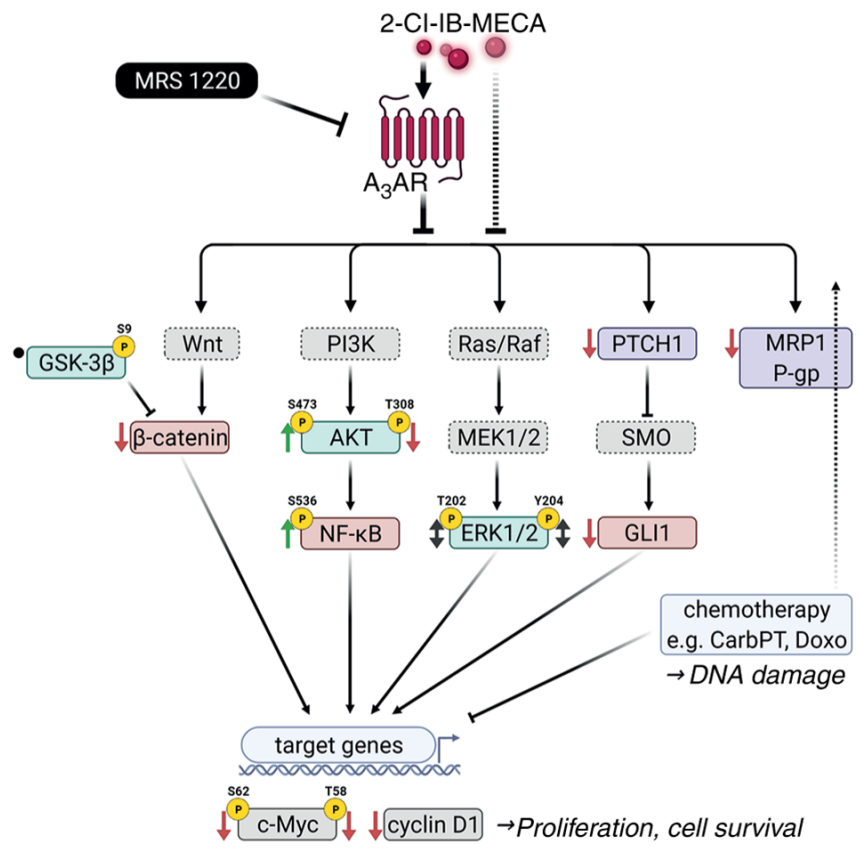

Figure 8. Schematic summary of the effect of 2-Cl-IB-MECA on intracellular signaling pathways. 2-Cl-IB-MECA modulates key components of the PI3K/AKT/NF- $\mathrm{BB}$, Ras/Raf/MEK1/2/ERK1/2, Wnt/ $\beta$-catenin, and Shh/Ptch/Gli signaling pathways together with MRD proteins, MRP1 and P-gp, leading to inhibition of JoPaca-1 and Hep-3B cancer cell proliferation and survival. In cooperation with chemotherapeutic agents, carboplatin and doxorubicin, 2-Cl-IB-MECA synergistically enhances their cytotoxicity. Studied proteins are indicated using solid line frames, while the others are indicated using dashed line frames. Observed effects of 2-Cl-IB-MECA treatment are designated by $\downarrow$ (inhibition/downregulation), $\uparrow$ (activation/upregulation), $\leftrightarrow$ (context-dependent upregulation/downregulation), and $\bullet$ (no changes). $\mathrm{A}_{3} \mathrm{AR}, \mathrm{A}_{3}$ adenosine receptor; CarbPT, carboplatin; Doxo, doxorubicin; Gli1, Glioma-associated oncogene homolog zinc finger protein 1 ; GSK-3 $\beta$, glycogen synthase kinase 3 $\beta$; MRP1, multidrug-resistance-associated protein 1; P-gp, P-glycoprotein; Ptch1, Patched 1; Shh, Sonic hedgehog; SMO, Smoothened; p, phosphorylated; 2-Cl-IB-MECA, 2-chloro-N6-(3-iodobenzyl)5'-N-methylcarboxamidoadenosine; MRS 1220, N-[9-Chloro-2-(2-furanyl) (1,2,4)-triazolo(1,5-c)quinazolin-5-yl]benzene acetamide.

exclusively at high 2-Cl-IB-MECA concentrations $\left(\sim \mathrm{IC}_{75}\right)$ and low 2-Cl-IB-MECA concentrations with 5-FU and gemcitabine at $\sim \mathrm{IC}_{50}$.

\section{Discussion}

In the present study, the antitumor mechanism of 2-Cl-IB-MECA in the JoPaca-1 and Hep-3B cell lines was analyzed (Fig. 8). The JoPaca-1 cell line is an established cellular model for pancreatic carcinoma with high tumorigenic potential; it shows clonal heterogeneity and aggressiveness, thus resembling primary tumors (34). To the best of our knowledge, the present study is the first to characterize the effect of 2-Cl-IB-MECA in the JoPaca-1 cell line in vitro. On the contrary, the Hep-3B HCC cell line is a well-defined tumorigenic cell line that has features of non-differentiated cells prone to EMT (36).

Initially, a MTS assay was performed using twelve tumor and two non-tumor cell lines to analyze the general cytotoxic effect of 2-Cl-IB-MECA against several tumor types. 2-Cl-IB-MECA was cytotoxic not only for the JoPaca-1 and Hep-3B cell lines, but also for other types of cancer cells in vitro.
From the results using the JoPaca-1 and Hep-3B cell lines, the cytotoxicity-inducing concentration of 2-Cl-IB-MECA was used for further experiments. Most importantly, the detrimental effects of 2-Cl-IB-MECA (Table I; Fig. 1D and E) were selective for cancer cells. The exact mechanism of 2-Cl-IB-MECA selectivity toward tumor cells has not yet been revealed; however, the results are consistent with previous findings from other tumor models (11), where the overexpression of $\mathrm{A}_{3} \mathrm{AR}$ in tumor vs. adjacent tissue was analyzed with respect to the responsiveness of cells to $\mathrm{A}_{3} \mathrm{AR}$-targeted therapy. The results from the present study showed that $\mathrm{A}_{3} \mathrm{AR}$ protein expression level was exclusive to cancer cells (Fig. 1C) and the higher $\mathrm{IC}_{50}$ values with respect to 2-Cl-IB-MECA in combination with MRS1220 (Fig. 1D and E) also corroborate this possibility. Next, $A_{3} A R$ functional assay was performed to determine the activating and inhibiting concentrations of 2-Cl-IB-MECA and MRS 1220, respectively, for use throughout the study (Fig. 1B). The results of which are consistent with previous studies $(15,66)$.

Studies show that 2-Cl-IB-MECA and its predecessor, IB-MECA disrupt cell cycle progression $(56,67)$. In the present study, 2-Cl-IB-MECA induced cell cycle arrest in the $\mathrm{G}_{0} / \mathrm{G}_{1}$ phase with an associated decrease in the number of cells in the S phase (Fig. 2A and B) and inhibited DNA, and RNA synthesis (Fig. 2E and F). Furthermore, inhibition of DNA and RNA synthesis was previously ascribed to an AdoR-independent anticancer mechanism in other adenosine analogues, e.g. clofarabine, fludarabine and 8-Cl-Ado (9). MRS 1220 was found to significantly reverse 2-Cl-IB-MECA-mediated inhibition of DNA and RNA synthesis in the present study. Notably, $20 \mu \mathrm{M}$ 2-Cl-IB-MECA was cytotoxic for at least $50 \%$ of the cell population (Fig. 1D and E); however, the number of apoptotic cells in the $\mathrm{subG}_{1}$ population were inconspicuous (Fig. 2C), suggesting another more prevalent type of cell death in this system.

2-Cl-IB-MECA has been described as a partially biased signaling molecule (68). Biased agonism could be particularly useful for eliciting the sole therapeutic effect while reducing risks of side effects $(29,30)$. $A_{3} A R$ is known to undergo rapid desensitization and internalization, and is thereafter degraded or recycled back to the surface to mediate its signaling (69). The observed differences in the protein expression levels of $A_{3} A R$ between the JoPaca-1 and Hep-3B cell line after 2-Cl-IB-MECA stimulation might contribute to the engagement of distinct molecular pathways (Fig. 3).

The effects of 2-Cl-IB-MECA on three important proliferative pathways, that are often deregulated in cancer, were investigated to reveal the predominant signaling cascade that is downregulated by 2-Cl-IB-MECA in the JoPaca-1 and Hep-3B cell line. $A_{3}$ AR is a GPCR interchangeably associated with $G_{i / o}$ and $G_{q}$ proteins, depending on various factors (10). As such, $A_{3}$ AR could mediate signaling either via the $\alpha_{i / o}, \alpha_{q}$ or $\beta / \gamma$ subunits of the $G$ protein. The $\beta / \gamma \mathrm{G}$ protein subunit activates the PI3K/AKT pathway which, in turn, leads to the phosphorylation of NF- $\kappa \mathrm{B}$ at Ser ${ }^{536}$, enhanced nuclear localization, and transactivation, presumably leading to pro-survival and inflammatory signals (70). Phosphorylation of AKT at Ser ${ }^{473}$ also leads to cross-activation of ERK1/2 signaling. The MAP kinases ERK1/2 could again be activated via the $\mathrm{G} \alpha_{\mathrm{q}}$ protein subunit of the GPCR and protein kinase $C$, if the activation of 
this pathway is a predominant event. Furthermore, the protein kinase $\mathrm{C}$ pathway may also promote $\mathrm{NF}-\kappa \mathrm{B}$ stimulation (71). The apparent and surprising activation of AKT kinase and $\mathrm{NF}-\kappa \mathrm{B}$ in the present study (Fig. 3) could be possibly explained by the endoplasmic reticulum (ER) stress response pathway (72). AKT kinase and NF- $\mathrm{NB}$ could be activated during the unfolded protein response, an event during which the ER cannot meet the high protein production demand and cannot ensure their proper folding $(73,74)$. Phosphorylation of both residues is important for, but not reciprocally dependent on, high AKT kinase activity (75). Notably, Vincent et al (76) showed association between phosphorylation of AKT at $\mathrm{Thr}^{308}$ and proliferation of human non-small cell lung carcinoma samples. No association was observed for phosphorylation at $\mathrm{Ser}^{473}$. A decrease in AKT kinase phosphorylation at $\mathrm{Thr}^{308}$ was found after 2-Cl-IB-MECA treatment (Fig. 3), which aligns with the overall decrease in proliferation in the JoPaca-1 and Hep-3B cell lines. In addition, a study by Yung et al (77) demonstrated increased $\mathrm{Ser}^{473}$ phosphorylation alongside decreased $\mathrm{Thr}^{308}$ AKT residues that were modulated by ER stress in choriocarcinoma cells. In addition, previous descriptions of the ER stress response in tumor cells related to treatments with adenosine (78) and its analogue AICAR (79) further supports the notion.

When an agonist binds, $\mathrm{A}_{3} \mathrm{AR}$, as a $\mathrm{G} \alpha_{\mathrm{i}}$-coupled receptor, inhibits adenylyl cyclase activity and, thus, protein kinase A, which would otherwise block GSK-3 $\beta$ kinase function (80). If the $G \alpha_{i}$ subunit was the preferred route, the total GSK-3 $\beta$ protein expression level should increase and pGSK-3 $\beta$ (inactive form) levels should reduce. However, neither GSK-3 $\beta$ protein accumulation nor pGSK-3 $\beta$ reduction was observed (Fig. 4 ). This observation contradicts previous reports of GSK-3 $\beta$ kinase upregulation or activation by 2 -Cl-IB-MECA $(13,20)$ or its predecessor IB-MECA (81). Still, both cell lines showed decreased $\beta$-catenin expression after 2 -Cl-IB-MECA treatment (Fig. 4). Furthermore, functional assays revealed for the first time early blockage of $\beta$-catenin binding to the TCF/LEF transcription factor and, hence, the inhibition of its transcriptional activity in reporter cell lines with 2-Cl-IB-MECA treatment (Fig. 5). The effects were more evident within reporter systems representing the defective $\mathrm{Wnt} / \beta$-catenin pathway (Fig. 5B). This finding could be particularly useful for HCC, which often exhibits $\beta$-catenin mutations $(58,82)$. In addition, MRS 1220 pre-treatment had limited effect on the reporter systems.

The Shh/Ptch/Gli signaling pathway, another evolutionarily conserved pathway, was also analyzed. Treatment with 2-Cl-IB-MECA resulted in decreased expression of both the transcription factor Gli1 and the receptor Ptch1 (Fig. 4), two key molecules in the Shh signaling pathway. Notably, cyclin D1 and c-Myc are downstream targets, where several proliferation pathways, including $\mathrm{Sh} / \mathrm{Ptch} / \mathrm{Gli}$ and $\mathrm{Wnt} / \beta$-catenin, converge. Among other molecules, activated NF- $\kappa$ B was previously shown to increase cyclin D1 and c-Myc expression to stimulate proliferation $(83,84)$. In the present study, cyclin D1 and c-Myc protein expression level, including c-Myc phosphorylated forms, were significantly downregulated (Fig. 4) despite AKT and NF- $\mathrm{BB}$ phosphorylation (Fig. 3), indicating that neither $\mathrm{AKT}$ nor $\mathrm{NF}-\kappa \mathrm{B}$ is a predominant antitumor target for 2-Cl-IB-MECA. Instead, $\beta$-catenin impaired transcriptional activity and deregulated protein expression of
Gli1/Ptch1 are more likely to be the first steps, as the reporter assay and western blot data suggest. Furthermore, the results from the present study indicate reduction of the $\mathrm{Wnt} / \beta$-catenin pathway upon 2-Cl-IB-MECA treatment, that is independent of GSK-3 $\beta$ kinase status.

Regulation of upstream molecules (AKT, ERK and GSK-3 $\beta$ ) could be explained by stimulation of $A_{3} A R$ as a GPCR; however, MRS 1220 only partially reduced the effect of 2-Cl-IB-MECA on the protein expression levels of pAKT $\mathrm{Thr}^{308}, \mathrm{pNF}-\kappa \mathrm{B}, \mathrm{pGSK}-3 \beta, \beta$-catenin and c-Myc. Modulation of the expression level of pAKT Ser ${ }^{473}, \mathrm{pERK} 1 / 2$ and cyclin D1 was less dependent on MRS 1220 pre-treatment, suggesting that an $\mathrm{A}_{3} \mathrm{AR}$-independent mechanism also plays a role.

An increasing number of studies promote the use of adenosine analogues against invasive cancer cells with stem-like or chemoresistant phenotype $(55,56,85)$. So far, only a few studies suggest any association between 2-Cl-IB-MECA and MDR-associated transporters $(43,86)$. Therefore, the potential impact of 2-Cl-IB-MECA on MDR proteins, MRP1 and P-gp in the JoPaca-1 and Hep-3B cell lines was investigated. Treatment with 2-Cl-IB-MECA revealed decrease in the protein expression level of both MRP1 and P-gp (Fig. 6A-D), possibly offering a new tool for reducing chemoresistance in cancer cells. Furthermore, for the first time, it was found that 2-Cl-IB-MECA could also block the P-gp efflux (Fig. 6E). Notably, MRS 1220 was able to partially counteract this effect. The observed changes in MRP1 and P-gp protein expression levels are consistent with recent findings associating MRP1 and P-gp transporters, chemoresistance and the Hh transduction pathway $(61,65)$, and could complement the downregulation of the $\mathrm{Shh} / \mathrm{Ptch} / \mathrm{Gli}$ axis in the JoPaca-1 and Hep-3B cell lines treated with 2-Cl-IB-MECA. Previous research has also associated $\beta$-catenin activity with $\mathrm{P}$-gp expression (87). Collectively, the results from the present study indicate that 2-Cl-IB-MECA could downregulate MRP1 and $\mathrm{P}-\mathrm{gp}$ expression, and P-gp involvement in the transport of chemotherapeutics, as well as xenobiotics in general via the recruitment of $\mathrm{A}_{3} \mathrm{AR}$.

On the other hand, evidence for the enhancement of chemotherapeutic effects of clinically relevant drugs, that are mediated by $\mathrm{A}_{3} \mathrm{AR}$ agonists, in vitro and in vivo, is sparse. The use of 2-Cl-IB-MECA, together with cyclophosphamide, inhibited growth of B16-F10 melanoma cells and reduced the number of metastatic foci in murine lung (40). In addition, HCT116 colon carcinoma cells, as well as tumor-bearing mice, were successfully treated with a combination of the 2-Cl-IB-MECA predecessor, IB-MECA, with 5-FU (84). Soares et al $(41,42)$ showed that 2-Cl-IB-MECA potentiated paclitaxel cytotoxicity in human melanoma cells. Notably, they did not find 2-Cl-IB-MECA-elicited effects to be associated with $\mathrm{A}_{3} \mathrm{AR}$.

Therefore, possible synergistic/additive effects of 2-Cl-IB-MECA were analyzed when used with the following therapeutic agents from current anticancer protocols for HCC and pancreatic cancer: 5-FU, carboplatin, doxorubicin and gemcitabine. It was confirmed that 2-Cl-IB-MECA also facilitated the cytotoxic effects of carboplatin and doxorubicin in the JoPaca-1 (Fig. 7A) and Hep-3B (Fig. 7B) cell lines at several concentration ratios. By contrast, the combination of 2-Cl-IB-MECA with either 5-FU or gemcitabine showed 
synergy only if a high concentration of 2-Cl-IB-MECA was used. Surprisingly, synergistic effects were more profound in the JoPaca-1 cell line, which are generally more chemoresistant (34). Furthermore, the chemosensitizing effects of 2-Cl-IB-MECA were not enhanced with sequential treatment combinations (data not shown). Studies have shown that P-gp and MRP1 overexpression accompanies the acquired chemoresistance of the HCC cell lines, Hep-3B and HepG2 to doxorubicin in vitro. Buschauer et al (88) suggested that this phenomenon possibly occurs after transarterial chemoembolization followed by doxorubicin chemotherapy that targets residual HCC cells. Recently, inhibition of the $\mathrm{P}$-gp transporter improved doxorubicin anticancer effects in HCC cells (89). In addition, improved chemosensitivity to gemcitabine was previously shown in a murine model of pancreatic ductal adenocarcinoma after co-targeting the $\mathrm{Hh}$ signaling pathway (60). Taken together, the results from the present study on the chemosensitizing effect of 2-Cl-IB-MECA on cancer cell lines in vitro further support the potential of 2-Cl-IB-MECA for combination therapy for pancreatic and liver cancer.

Whether the effects of the adenosine analogue 2-Cl-IB-MECA are mediated by $\mathrm{A}_{3} \mathrm{AR}$ is an unrelenting question. The dependency of 2-Cl-IB-MECA on the $\mathrm{A}_{3} \mathrm{AR}$ receptor was analyzed for its cytotoxic effect by first showing that the JoPaca-1 and Hep-3B cells expressed $\mathrm{A}_{3} \mathrm{AR}$. In the present study, the $\mathrm{A}_{3}$-specific antagonist, MRS 1220 was used as a pharmacological tool for successful blocking of the receptor function and established the antagonist concentration that reliably blocked $\mathrm{A}_{3} \mathrm{AR}$ activity while remaining non-toxic for the cells $(0.1 \mu \mathrm{M})$. Indeed, MRS 1220 reduced 2-Cl-IB-MECA cytotoxicity towards cancer cell lines. However, there is always a possibility of off-target effects of a pharmacological inhibitor and further analyses are warranted. Notably, the responsiveness of a biological model to $\mathrm{A}_{3} \mathrm{AR}$ pharmacological treatments depends on the specific equilibrium between receptor, ligand (agonist) and any other modulator (antagonist) competing for the binding site, especially in an artificial system $(90,91)$. This phenomenon could explain the results from some studies demonstrating $\mathrm{A}_{3} \mathrm{AR}$-dependent $(13,56)$ and -independent effects $(92,93)$, as well as some studies supporting the effects of $0.1 \mu \mathrm{M}$ MRS $1220(54,55)$. Nonetheless, the cacophony of findings regarding MRS 1220 does not reduce the potential of 2-Cl-IB-MECA or novel derivatives arising from the adenosine structure. Furthermore, co-existing mechanisms that are dependent and independent of the adenosine receptor were described for other adenosine analogues $(9,81,94)$.

Collectively, the results from the present study provides further insights into 2-Cl-IB-MECA decreased proliferation of the HCC and pancreatic cancer cells (Fig. 8). 2-Cl-IB-MECA negatively regulated the $\mathrm{Wnt} / \beta$-catenin and $\mathrm{Shh} / \mathrm{Ptch} / \mathrm{Gli}$ pathways, and for the first time, it was shown that $\beta$-catenin transcriptional activity was reduced. The results from the present study also highlight the effect of 2-Cl-IB-MECA on MRP1 and P-gp transporters, and its potential for combination treatment with chemotherapeutic agents. Nonetheless, there are limitations of in vitro studies utilizing pharmacological tools and these finding should be further verified in knock-out models or animal studies.

\section{Acknowledgements}

The structure of 2-Cl-IB-MECA in Fig. 1 was created using MarvinSketch (ChemAxon). The schematic in Fig. 8 was created using BioRender.com.

\section{Funding}

The present study was supported by the European Regional Development Fund (Project ENOCH no. CZ.02.1.01/0.0/ 0.0/16_019/0000868), the Czech Ministry of Education, Youth and Sports (grant nos. EATRIS-CZ, LM2018133 and CZ-OPENSCREEN, LM2018130), the Czech Science Foundation (grant no. GACR 19-08124S) and the Technology Agency of the Czech Republic: Czech National Centres of Competence, project 'PerMed' Personalized Medicine - Diagnostics and Therapy (grant no. TN01000013).

\section{Availability of data and materials}

All the data generated and/or analyzed during this study are available from the corresponding author upon reasonable request.

\section{Authors' contributions}

JK, PD and MH conceptualized the study. JK and PD wrote the manuscript. JK, KL and AK designed and performed the experiments. JK, JV and PK analyzed the data. JK, PD and $\mathrm{MH}$ revised and edited the manuscript. $\mathrm{PD}$ and $\mathrm{MH}$ acquired the funding. JK and PD confirm the authenticity of all the raw data. All authors read and approved the final manuscript.

\section{Ethics approval and consent to participate}

Not applicable.

\section{Patient consent for publication}

Not applicable.

\section{Competing interests}

The authors declare that they have no competing interests.

\section{References}

1. Ferlay J, Ervik M, Lam F, Colombet M, Mery L, Piñeros M, Znaor A, Soerjomataram I and Bray F: Global cancer observatory: Cancer today. Lyon, France: International Agency for Research on Cancer, 2020. Available from: https://gco.iarc.fr/today. Accessed November 24, 2021.

2. Rawla P, Sunkara T and Gaduputi V: Epidemiology of pancreatic cancer: Global trends, etiology and risk factors. World J Oncol 10: 10-27, 2019.

3. Bray F, Ferlay J, Soerjomataram I, Siegel RL, Torre LA and Jemal A: Global cancer statistics 2018: GLOBOCAN estimates of incidence and mortality worldwide for 36 cancers in 185 countries. CA Cancer J Clin 68: 394-424, 2018.

4. Marquardt JU, Gomez-Quiroz L, Arreguin Camacho LO, Pinna F, Lee YH, Kitade M, Domínguez MP, Castven D, Breuhahn K, Conner EA, et al: Curcumin effectively inhibits oncogenic NF- $\mathrm{B}$ signaling and restrains stemness features in liver cancer. J Hepatol 63: 661-669, 2015.

5. Zeng SY, Pottler M, Lan B, Grutzmann R, Pilarsky C and Yang H: Chemoresistance in pancreatic cancer. Int J Mol Sci 20: 4504, 2019. 
6. Adamska A and Falasca M: ATP-binding cassette transporters in progression and clinical outcome of pancreatic cancer: What is the way forward? World J Gastroenterol 24: 3222-3238, 2018.

7. Lohitesh K, Chowdhury R and Mukherjee S: Resistance a major hindrance to chemotherapy in hepatocellular carcinoma: An insight. Cancer Cell Int 18: 44, 2018.

8. Liu A, Wu Q, Peng D, Ares I, Anadón A, Lopez-Torres B Martínez-Larrañaga MR, Wang X and Martínez MA: A novel strategy for the diagnosis, prognosis, treatment, and chemoresistance of hepatocellular carcinoma: DNA methylation. Med Res Rev 40: 1973-2018, 2020

9. Man S, Lu Y, Yin L, Cheng X and Ma L: Potential and promising anticancer drugs from adenosine and its analogs. Drug Discov Today 26: 1490-1500, 2021

10. Fredholm BB, IJzerman AP, Jacobson KA, Linden J and Müller CE: International union of basic and clinical pharmacology. LXXXI. Nomenclature and classification of adenosine receptors-an update. Pharmacol Rev 63: 1-34, 2011.

11. Madi L, Ochaion A, Rath-Wolfson L, Bar-Yehuda S, Erlanger A, Ohana G, Harish A, Merimski O, Barer F and Fishman P: The A3 adenosine receptor is highly expressed in tumor versus normal cells: Potential target for tumor growth inhibition. Clin Cancer Res 10: 4472-4479, 2004

12. Morello S, Petrella A, Festa M, Popolo A, Monaco M, Vuttariello E, Chiappetta G, Parente L and Pinto A: Cl-IB-MECA inhibits human thyroid cancer cell proliferation independently of A3 adenosine receptor activation. Cancer Biol Ther 7: 278-284, 2008

13. Bar-Yehuda S, Stemmer SM, Madi L, Castel D, Ochaion A, Cohen S, Barer F, Zabutti A, Perez-Liz G, Del Valle L and Fishman P: The A3 adenosine receptor agonist CF102 induces apoptosis of hepatocellular carcinoma via de-regulation of the Wnt and NF-kappaB signal transduction pathways. Int $\mathbf{J}$ Oncol 33: 287-295, 2008

14. Gessi S, Cattabriga E, Avitabile A, Gafa' R, Lanza G, Cavazzini L, Bianchi N, Gambari R, Feo C, Liboni A, et al: Elevated expression of A3 adenosine receptors in human colorectal cancer is reflected in peripheral blood cells. Clin Cancer Res 10: 5895-5901, 2004.

15. Kim HO,Ji XD, Siddiqi SM, Olah ME, Stiles GL and Jacobson KA: 2-Substitution of N6-benzyladenosine-5'-uronamides enhances selectivity for A3 adenosine receptors. J Med Chem 37: 3614-3621, 1994

16. Van Schaick EA, Jacobson KA, Kim HO, Ijzerman AP and Danhof M: Hemodynamic effects and histamine release elicited by the selective adenosine A3 receptor agonist 2-Cl-IB-MECA in conscious rats. Eur J Pharmacol 308: 311-314, 1996.

17. Wittendorp MC, Biber K and Boddeke HWGM: CL-IB-MECA induced release of CCL2 by astrocytes: Possible role for the adenosine A3 receptor? Naunyn-Schmiedeb Arch Pharmacol 369: R178, 2004.

18. Ge ZD, Peart JN, Kreckler LM, Wan TC, Jacobson MA, Gross GJ and Auchampach JA: Cl-IB-MECA [2-chloro-N6-(3-iodobenzyl) adenosine-5'-N-methylcarboxamide] reduces ischemia/reperfusion injury in mice by activating the A3 adenosine receptor. J Pharmacol Exp Ther 319: 1200-1210, 2006.

19. Coppi E, Cherchi F, Fusco I, Failli P, Vona A, Dettori I, Gaviano L, Lucarini E, Jacobson KA, Tosh DK, et al: Adenosine A3 receptor activation inhibits pronociceptive $\mathrm{N}$-type $\mathrm{Ca}^{2+}$ currents and cell excitability in dorsal root ganglion neurons. Pain 160: 1103-1118, 2019.

20. Cohen S, Stemmer SM, Zozulya G, Ochaion A, Patoka R, Barer F, Bar-Yehuda S, Rath-Wolfson L, Jacobson KA and Fishman P: CF102 an A3 adenosine receptor agonist mediates anti-tumor and anti-inflammatory effects in the liver. J Cell Physiol 226 : 2438-2447, 2011

21. Morello S, Sorrentino R, Montinaro A, Luciano A, Maiolino P Ngkelo A, Arra C, Adcock IM and Pinto A: NK1.1 cells and CD8 T cells mediate the antitumor activity of Cl-IB-MECA in a mouse melanoma model. Neoplasia 13: 365-373, 2011

22. Bar Yehuda S, Stemmer SM, Madi L, Castel D, Ochaion A, Cohen S, Barer F, Perez-Liz G, Del Valle L and Fishman P: Effect of CF102 on growth suppression and apoptosis in an orthotopic model of hepatocellular carcinoma. J Clin Oncol 26 (Suppl 15): S22113, 2008

23. Safadi R, Braun M, Francis A, Milgrom Y, Massarwa M, Hakimian D, Hazou W, Issachar A, Harpaz Z, Farbstein M, et al: Randomised clinical trial: A phase 2 double-blind study of namodenoson in non-alcoholic fatty liver disease and steatohepatitis. Aliment Pharmacol Ther 54: 1405-1415, 2021.
24. Stemmer SM, Manojlovic NS, Marinca MV, Petrov P, Cherciu N, Ganea D, Ciuleanu TE, Puscas IA, Beg MS, Purcell WT, et al: A phase II, randomized, double-blind, placebo-controlled trial evaluating efficacy and safety of namodenoson (CF102), an A3 adenosine receptor agonist (A3AR), as a second-line treatment in patients with Child-Pugh B (CPB) advanced hepatocellular carcinoma (HCC). J Clin Oncol 37 (Suppl 15): S2503, 2019

25. Stemmer SM, Manojlovic NS, Marinca MV, Petrov P, Cherciu N, Ganea D, Ciuleanu TE, Pusca IA, Beg MS, Purcell WT, et al: Namodenoson in advanced hepatocellular carcinoma and Child-Pugh B cirrhosis: Randomized placebo-controlled clinical trial. Cancers (Basel) 13: 187, 2021.

26. Ohana G, Cohen S, Rath-Wolfson L and Fishman P: A3 adenosine receptor agonist, CF102, protects against hepatic ischemia/reperfusion injury following partial hepatectomy. Mol Med Rep 14: 4335-4341, 2016

27. David M, Gospodinov DK, Gheorghe N, Mateev GS, Rusinova MV, Hristakieva E, Solovastru LG, Patel RV, Giurcaneanu C, Hitova MC, et al: Treatment of plaque-type psoriasis with oral CF101: Data from a phase II/III multicenter, randomized, controlled trial. J Drugs Dermatol 15: 931-938, 2016.

28. Storme J, Tosh DK, Gao ZG, Jacobson KA and Stove CP: Probing structure-activity relationship in $\beta$-arrestin 2 recruitment of diversely substituted adenosine derivatives. Biochem Pharmacol 158: 103-113, 2018.

29. Suresh RR, Jain S, Chen Z, Tosh DK, Ma Y, Podszun MC, Rotman Y, Salvemini D and Jacobson KA: Design and in vivo activity of $\mathrm{A}_{3}$ adenosine receptor agonist prodrugs. Purinergic Signal 16: 367-377, 2020

30. Pottie E, Tosh DK, Gao ZG, Jacobson KA and Stove CP Assessment of biased agonism at the $\mathrm{A}_{3}$ adenosine receptor using $\beta$-arrestin and miniG $\alpha_{i}$ recruitment assays. Biochem Pharmacol 177: 113934, 2020.

31. Kim SJ, Min HY, Chung HJ, Park EJ, Hong JY, Kang YJ, Shin DH, Jeong LS and Lee SK: Inhibition of cell proliferation through cell cycle arrest and apoptosis by thio-Cl-IB-MECA, a novel A3 adenosine receptor agonist, in human lung cancer cells. Cancer Lett 264: 309-315, 2008.

32. Baltos JA, Paoletta S, Nguyen AT, Gregory KJ, Tosh DK, Christopoulos A, Jacobson KA and May LT: Structure-activity analysis of biased agonism at the human adenosine A3 receptor. Mol Pharmacol 90: 12-22, 2016.

33. Vecchio EA, Baltos JA, Nguyen ATN, Christopoulos A, White PJ and May LT: New paradigms in adenosine receptor pharmacology: Allostery, oligomerization and biased agonism. Br J Pharmacol 175: 4036-4046, 2018.

34. Fredebohm J, Boettcher M, Eisen C, Gaida $\mu$ M, Heller A, Keleg S, Tost J, Greulich-Bode KM, Hotz-Wagenblatt A, Lathrop M, et al: Establishment and characterization of a highly tumourigenic and cancer stem cell enriched pancreatic cancer cell line as a well defined model system. PLoS One 7: e48503, 2012.

35. Novak I, Yu H, Magni L and Deshar G: Purinergic signaling in pancreas-from physiology to therapeutic strategies in pancreatic cancer. Int J Mol Sci 21: 8781, 2020.

36. Qiu GH, Xie X, Xu F, Shi XH, Wang Y and Deng L: Distinctive pharmacological differences between liver cancer cell lines HepG2 and Hep3B. Cytotechnology 67: 1-12, 2015.

37. Torres A, Vargas Y, Uribe D, Jaramillo C, Gleisner A Salazar-Onfray F, López MN, Melo R, Oyarzún C, San Martín R and Quezada C: Adenosine A3 receptor elicits chemoresistance mediated by multiple resistance-associated protein-1 in human glioblastoma stem-like cells. Oncotarget 7: 67373-67386, 2016.

38. Torres Á, Erices JI, Sanchez F, Ehrenfeld P, Turchi L, Virolle T, Uribe D, Niechi I, Spichiger C, Rocha JD, et al: Extracellular adenosine promotes cell migration/invasion of glioblastoma stem-like cells through $\mathrm{A}_{3}$ Adenosine Receptor activation under hypoxia. Cancer Lett 446: 112-122, 2019.

39. Montraveta A, Xargay-Torrent S, López-Guerra M, Rosich L, Pérez-Galán P, Salaverria I, Beà S, Kalko SG, de Frias M, Campàs $\mathrm{C}$, et al: Synergistic anti-tumor activity of acadesine (AICAR) in combination with the anti-CD20 monoclonal antibody rituximab in in vivo and in vitro models of mantle cell lymphoma. Oncotarget 5: 726-739, 2014.

40. Fishman P, Bar-Yehuda S, Barer F, Madi L, Multani AS and Pathak S: The A3 adenosine receptor as a new target for cancer therapy and chemoprotection. Exp Cell Res 269: 230-236, 2001.

41. Soares AS, Costa VM, Diniz C and Fresco P: The combination of Cl-IB-MECA with paclitaxel: A new anti-metastatic therapeutic strategy for melanoma. Cancer Chemother Pharmacol 74: $847-860,2014$ 
42. Soares AS, Costa VM, Diniz C and Fresco P: Potentiation of cytotoxicity of paclitaxel in combination with Cl-IB-MECA in human C32 metastatic melanoma cells: A new possible therapeutic strategy for melanoma. Biomed Pharmacother 67: 777-789, 2013

43. Mlejnek P, Dolezel P and Kosztyu P: P-glycoprotein mediates resistance to A3 adenosine receptor agonist 2-chloro-N6-(3-io dobenzyl)-adenosine-5'-n-methyluronamide in human leukemia cells. J Cell Physiol 227: 676-685, 2012.

44. Abel B, Tosh DK, Durell SR, Murakami M, Vahedi S, Jacobson KA and Ambudkar SV: Evidence for the interaction of $\mathrm{A}_{3}$ adenosine receptor agonists at the drug-binding site(s) of human P-glycoprotein (ABCB1). Mol Pharmacol 96: 180-192, 2019.

45. Noskova V, Dzubak P, Kuzmina G, Ludkova A, Stehlik D, Trojanec R, Janostakova A, Korinkova G, Mihal V and Hajduch M: In vitro chemoresistance profile and expression/function of MDR associated proteins in resistant cell lines derived from CCRF-CEM, K562, A549 and MDA MB 231 parental cells. Neoplasma 49: 418-425, 2002

46. Le Poul E, Hisada S, Mizuguchi Y, Dupriez VJ, Burgeon E and Detheux M: Adaptation of aequorin functional assay to high throughput screening. J Biomol Screen 7: 57-65, 2002.

47. Borková L, Frydrych I, Jakubcová N, Adámek R, Lišková B, Gurská S, Medvedíková M, Hajdúch M and Urban M: Synthesis and biological evaluation of triterpenoid thiazoles derived from betulonic acid, dihydrobetulonic acid, and ursonic acid. Eur J Med Chem 185: 111806, 2020.

48. Chou TC: Theoretical basis, experimental design, and computerized simulation of synergism and antagonism in drug combination studies. Pharmacol Rev 58: 621-681, 2006.

49. Chou TC and Talalay P: Quantitative analysis of dose-effect relationships: The combined effects of multiple drugs or enzyme inhibitors. Adv Enzyme Regul 22: 27-55, 1984.

50. Bourderioux A, Naus P, Perlíková P, Pohl R, Pichová I, Votruba I Dzubák P, Konecný P, Hajdúch M, Stray KM, et al: Synthesis and significant cytostatic activity of 7-hetaryl-7-deazaadenosines. J Med Chem 54: 5498-5507, 2011.

51. Schneider CA, Rasband WS and Eliceiri KW: NIH image to imageJ: 25 Years of image analysis. Nat Methods 9: 671-675, 2012

52. Dzubák P, Hajdúch M, Gazák R, Svobodová A, Psotová J, Walterová D, Sedmera P and Kren V: New derivatives of silybin and 2,3-dehydrosilybin and their cytotoxic and P-glycoprotein modulatory activity. Bioorg Med Chem 14: 3793-3810, 2006.

53. Borea PA, Varani K, Vincenzi F, Baraldi PG, Tabrizi MA Merighi S and Gessi S: The A3 adenosine receptor: History and perspectives. Pharmacol Rev 67: 74-102, 2015.

54. Laudadio MA and Psarropoulou C: The A3 adenosine receptor agonist 2-Cl-IB-MECA facilitates epileptiform discharges in the CA3 area of immature rat hippocampal slices. Epilepsy Res 59: 83-94, 2004

55. Jafari SM, Panjehpour M, Aghaei M, Joshaghani HR and Enderami SE: A3 adenosine receptor agonist inhibited survival of breast cancer stem cells via GLI-1 and ERK1/2 pathway. J Cell Biochem 118: 2909-2920, 2017.

56. Merighi S, Benini A, Mirandola P, Gessi S, Varani K, Leung E, Maclennan S and Borea PA: A3 adenosine receptor activation inhibits cell proliferation via phosphatidylinositol 3-kinase/Akt-dependent inhibition of the extracellular signal-regulated kinase 1/2 phosphorylation in A375 human melanoma cells. J Biol Chem 280: 19516-19526, 2005.

57. Borea PA, Gessi S, Merighi S, Vincenzi F and Varani K Pharmacology of adenosine receptors: The state of the art Physiol Rev 98: 1591-1625, 2018.

58. Haines K, Sarabia SF, Alvarez KR, Tomlinson G, Vasudevan SA Heczey AA, Roy A, Finegold MJ, Parsons DW, Plon SE, et al: Characterization of pediatric hepatocellular carcinoma reveals genomic heterogeneity and diverse signaling pathway activation. Pediatr Blood Cancer 66: e27745, 2019.

59. Jones S, Zhang XS, Parsons DW, Lin JC, Leary RJ, Angenendt $P$, Mankoo P, Carter H, Kamiyama H, Jimeno A, et al: Core signaling pathways in human pancreatic cancers revealed by global genomic analyses. Science 321: 1801-1806, 2008.

60. Olive KP, Jacobetz MA, Davidson CJ, Gopinathan A, McIntyre D, Honess D, Madhu B, Goldgraben MA, Caldwell ME, Allard D, et al: Inhibition of Hedgehog signaling enhances delivery of chemotherapy in a mouse model of pancreatic cancer. Science 324: 1457-1461, 2009.

61. Ding J, Zhou XT, Zou HY and Wu J: Hedgehog signaling pathway affects the sensitivity of hepatoma cells to drug therapy through the ABCC1 transporter. Lab Invest 97: 819-832, 2017.
62. He TC, Sparks AB, Rago C, Hermeking H, Zawel L, da Costa LT, Morin PJ, Vogelstein B and Kinzler KW: Identification of c-MYC as a target of the APC pathway. Science 281: 1509-1512, 1998.

63. Tetsu $\mathrm{O}$ and McCormick F: Beta-catenin regulates expression of cyclin D1 in colon carcinoma cells. Nature 398: 422-426, 1999.

64. Spoelstra EC, Westerhoff HV, Pinedo HM, Dekker H and Lankelma J: The multidrug-resistance-reverser verapamil interferes with cellular P-glycoprotein-mediated pumping of daunorubicin as a non-competing substrate. Eur J Biochem 221: 363-373, 1994.

65. Queiroz KCS, Ruela-de-Sousa RR, Fuhler GM, Aberson HL, Ferreira CV, Peppelenbosch MP and Spek CA: Hedgehog signaling maintains chemoresistance in myeloid leukemic cells. Oncogene 29: 6314-6322, 2010.

66. Jacobson KA: Adenosine A3 receptors: Novel ligands and paradoxical effects. Trends Pharmacol Sci 19: 184-191, 1998.

67. Aghaei M, Panjehpour M, Karami-Tehrani F and Salami S: Molecular mechanisms of A3 adenosine receptor-induced G1 cell cycle arrest and apoptosis in androgen-dependent and independent prostate cancer cell lines: Involvement of intrinsic pathway. J Cancer Res Clin Oncol 137: 1511-1523, 2011.

68. Gao ZG and Jacobson KA: Translocation of arrestin induced by human A3 adenosine receptor ligands in an engineered cell line: Comparison with $\mathrm{G}$ protein-dependent pathways. Purinergic Signal 4: S78-S79, 2008.

69. Mundell S and Kelly E: Adenosine receptor desensitization and trafficking. Biochim Biophys Acta 1808: 1319-1328, 2011.

70. Hu J, Nakano H, Sakurai H and Colburn NH: Insufficient p65 phosphorylation at S536 specifically contributes to the lack of NF-kappaB activation and transformation in resistant JB6 cells. Carcinogenesis 25: 1991-2003, 2004

71. De Luca A, Maiello MR, D'Alessio A, Pergameno $M$ and Normanno N: The RAS/RAF/MEK/ERK and the PI3K/AKT signalling pathways: Role in cancer pathogenesis and implications for therapeutic approaches. Expert Opin Ther Targets 16 (Suppl 2): S17-S27, 2012.

72. Hasnain SZ, Lourie R, Das I, Chen AC and McGuckin MA: The interplay between endoplasmic reticulum stress and inflammation. Immunol Cell Biol 90: 260-270, 2012.

73. Tam AB, Mercado EL, Hoffmann A and Niwa M: ER stress activates NF- $\kappa \mathrm{B}$ by integrating functions of basal IKK activity, IRE1 and PERK. PLoS One 7: e45078, 2012.

74. Makhov P, Naito S, Haifler M, Kutikov A, Boumber Y, Uzzo RG and Kolenko VM: The convergent roles of NF- $\kappa \mathrm{B}$ and ER stress in sunitinib-mediated expression of pro-tumorigenic cytokines and refractory phenotype in renal cell carcinoma. Cell Death Dis 9: 374,2018 .

75. Alessi DR, Andjelkovic M, Caudwell B, Cron P, Morrice N, Cohen $\mathrm{P}$ and Hemmings BA: Mechanism of activation of protein kinase B by insulin and IGF-1. EMBO J 15: 6541-6551, 1996.

76. Vincent EE, Elder DJ, Thomas EC, Phillips L, Morgan C, Pawade J, Sohail M, May MT, Hetzel MR and Tavaré JM: Akt phosphorylation on Thr308 but not on Ser473 correlates with Akt protein kinase activity in human non-small cell lung cancer. Br J Cancer 104: 1755-1761, 2011.

77. Yung HW, Charnock-Jones DS and Burton GJ: Regulation of AKT phosphorylation at Ser473 and Thr308 by endoplasmic reticulum stress modulates substrate specificity in a severity dependent manner. PLoS One 6: e17894, 2011.

78. Wu LF, Wei BL, Guo YT, Ye YQ, Li GP, Pu ZJ and Feng JL: Apoptosis induced by adenosine involves endoplasmic reticulum stress in EC109 cells. Int J Mol Med 30: 797-804, 2012

79. Nie J, Liu A, Tan Q, Zhao K, Hu K, Li Y, Yan B and Zhou L: AICAR activates ER stress-dependent apoptosis in gallbladder cancer cells. Biochem Biophys Res Commun 482: 246-252, 2017.

80. Ding L and Billadeau DD: Glycogen synthase kinase-3 $\beta$ : A novel therapeutic target for pancreatic cancer. Expert Opin Ther Targets 24: 417-426, 2020.

81. Fishman P, Bar Yehuda S, Stemmer SM and Madi L: CF101 enhances the apoptotic effect of chemotherapy on colon and pancreatic carcinoma cell lines: Molecular mechanisms involved. J Clin Oncol 22 (Suppl 14): S3173, 2004.

82. Kwee SA and Tiirikainen M: Beta-catenin activation and immunotherapy resistance in hepatocellular carcinoma: Mechanisms and biomarkers. Hepatoma Res 7: 8, 2021.

83. Hinz M, Krappmann D, Eichten A, Heder A, Scheidereit C and Strauss M: NF-kappaB function in growth control: Regulation of cyclin D1 expression and G0/G1-to-S-phase transition. Mol Cell Biol 19: 2690-2698, 1999. 
84. Bar-Yehuda S, Madi L, Silberman D, Gery S, Shkapenuk M and Fishman P: CF101, an agonist to the A3 adenosine receptor, enhances the chemotherapeutic effect of 5-fluorouracil in a colon carcinoma murine model. Neoplasia 7: 85-90, 2005.

85. Varani K, Vincenzi F, Targa M, Paradiso B, Parrilli A, Fini M, Lanza $\mathrm{G}$ and Borea PA: The stimulation of $\mathrm{A}(3)$ adenosine receptors reduces bone-residing breast cancer in a rat preclinical model. Eur J Cancer 49: 482-491, 2013.

86. Frydrych I, Dolezel P and Mlejnek P: P-glycoprotein overexpression confers resistance to $\mathrm{A} 3$ adenosine receptor agonists 2-chloro-N6-(3-iodobenzyl)-adenosine-5'-N-methyluronamide (Cl-IB-MECA) in human leukemia cells. Purinergic Signal 4 (Suppl 1): S1-S210, 2008.

87. Lim JC, Kania KD, Wijesuriya H, Chawla S, Sethi JK, Pulaski L, Romero IA, Couraud PO, Weksler BB, Hladky SB and Barrand MA: Activation of beta-catenin signalling by GSK-3 inhibition increases p-glycoprotein expression in brain endothelial cells. J Neurochem 106: 1855-1865, 2008.

88. Buschauer S, Koch A, Wiggermann P, Müller M and Hellerbrand C: Hepatocellular carcinoma cells surviving doxorubicin treatment exhibit increased migratory potential and resistance to doxorubicin re-treatment in vitro. Oncol Lett 15: 4635-4640, 2018.

89. Yin W, Xiang D, Wang T, Zhang Y, Pham CV, Zhou S, Jiang G, Hou Y, Zhu Y, Han Y, et al: The inhibition of ABCB1/MDR1 or ABCG2/BCRP enables doxorubicin to eliminate liver cancer stem cells. Sci Rep 11: 10791, 2021.
90. Hoare SRJ: The problems of applying classical pharmacology analysis to modern in vitro drug discovery assays: Slow binding kinetics and high target concentration. SLAS Discov 26: 835-850, 2021.

91. Fredholm BB: Adenosine receptors as drug targets. Exp Cell Res 316: 1284-1288, 2010

92. Kim SG, Ravi G, Hoffmann C, Jung YJ, Kim M, Chen A and Jacobson KA: p53-Independent induction of Fas and apoptosis in leukemic cells by an adenosine derivative, Cl-IB-MECA. Biochem Pharmacol 63: 871-880, 2002.

93. Mlejnek P, Dolezel P and Frydrych I: Effects of synthetic A3 adenosine receptor agonists on cell proliferation and viability are receptor independent at micromolar concentrations. J Physiol Biochem 69: 405-417, 2013.

94. Jajoo S, Mukherjea D, Watabe K and Ramkumar V: Adenosine A(3) receptor suppresses prostate cancer metastasis by inhibiting NADPH oxidase activity. Neoplasia 11: 1132-1145, 2009.

This work is licensed under a Creative Commons Attribution-NonCommercial-NoDerivatives 4.0 International (CC BY-NC-ND 4.0) License. 